\title{
Harmful Experiences Associated with Emotional Eating of Iranian Obese Women: A Phenomenological Study
}

\author{
Ehteram Ebrahimi ${ }^{1}$, Fatemeh Mohammadi Shirmahaleh ${ }^{2}$, Mojtaba Habibi ${ }^{3}$, \\ Marjan Mardani Hamooleh ${ }^{4}$
}

\begin{abstract}
Background \& Aims: Emotional eating is defined as the tendency to eat in response to stress or negative emotions in order to overcome negative emotions. According to research evidence, emotional eating is harmful to health. For example, emotional eating is associated with weight gain, increased risk of type 2 diabetes, metabolic syndrome, high blood pressure, and hyperlipidemia. Therefore, it is important to identify the factors that cause emotional eating to be harmful, as it helps us to get a deeper insight into emotional eating and its harms and plan more effective educational and psychological interventions to manage emotional eating. To do this, we need to analyze the experiences of people who have had emotional eating, to explore and explain this behavior from their point of view. As a result, we can identify the various psychological, social, and cultural dimensions of emotional eating. In addition, research evidence shows that emotional eating is more common in obese people than normal weight people, and women are more vulnerable to emotional eating than men. In addition to being universal, emotional eating behavior also has culture-related characteristics. According to these points, the aim of this study was to explain the harmfulness of emotional eating in young Iranian obese women.

Materials \& Methods: The present study was conducted using a qualitative method and a hermeneutic phenomenological approach in 2020. Participants in this study were 17 young women aged 25 - 45 years living in Kermanshah or Karaj, with emotional eating experience and a body mass index of 30 or higher. Pregnant women were not included in this study due to their different body mass index. Participants were selected using purposive sampling method with maximum diversity approach. Data were collected through in-depth individual and face-to-face interviews. Sampling and interviews continued until the data saturation stage. The main questions asked of the participants during the interview were as follows: 1) Describe one of your emotional eating experiences and explain the thoughts, ideas, emotions and physical feelings that led you to eat at that time. 2) What other experience in your life is similar to this experience, and what does it mean to you? 3) Under what circumstances do you have the most emotional eating? And what do you think the relationship between these conditions and emotional eating means? 4) What is the difference between the times when you eat emotionally and the times when you eat normally? Also, exploratory questions were asked to analyze the deeper layers of the participants' lived experiences. Some of the exploratory questions asked in the present study were as follows: What did you mean by ....? Could you explain more? Please give an example in this regard? Data analysis began at the same time as data collection process. Dickelman's 7-step method was used to analyze the data.

Results: In data analysis, a major theme emerged called "harmful companions" which showed that while participants experienced emotional eating, some other experiences accompanied their emotional eating, causing emotional eating to be harmful for these people. The main theme of "harmful companions" consists of seven subthemes named lack of self-control in eating behavior, unconscious eating, body abuse, contradictory experiences, eating addiction, excessive eating of certain foods, and secretive eating. Lack of self-control in eating behavior
\end{abstract}

\footnotetext{
1. Department of Psychology, Karaj Branch, Islamic Azad University, Karaj, Iran

2. Department of Psychology, Karaj Branch, Islamic Azad University, Karaj, Iran (Corresponding author) Tel:09126081389 $\quad$ Email:Fatemeh.mohamadi@kiau.ac.ir

3. Health Promotion Research Center, Department of Health Psychology, School of Behavioral Sciences \& Mental Health, Iran University of Medical Sciences. Tehran, Iran

${ }^{4}$. Department of Psychiatric Nursing, Nursing Care Research Center, School of Nursing and Midwifery, Iran University of Medical Sciences, Tehran, Iran
} 
means that emotional eaters do not have enough control over their eating behavior and their emotional eating is accompanied by fast eating, overeating, eating regardless of food quality, swallowing unchewed food, eating at the wrong time, and etc. The sub- theme of "unconscious eating" includes those experiences accompanying emotional eating that are not within the control of the conscious mind, and includes eating without consciousness, eating without will, eating involuntarily, eating without thinking, eating without purpose, unwanted eating, and eating without the right to choose. The sub- theme of "body abuse" refers to the victimization of the body, especially the gastrointestinal tract, during emotional eating experiences, and includes distracting from negative emotions by engaging the mouth and stomach through eating, replacing pain caused by filling the stomach with psychological pain of anxiety and chewing foods with clenching teeth to vent anger. The sub- theme of "contradictory experiences" includes the functions of positive and negative emotional eating and contradictions in attitude, feelings, and behavior of participants during emotional eating; Like enjoying eating but with a sense of shame for how you eat, eating pleasantly but with a guilty conscience; eating with craving but without pleasure, eating with craving but unwanted and the necessity of eating unnecessary. The sub- theme of "eating addiction" includes quasi-addictive traits found in emotional eaters, such as; mental temptation to eat, eating out of habit, physical urge to eat, psychological dependence on eating, compulsive eating, and searching behavior to find food. The sub- theme of "excessive eating of certain foods" means that although the participants' overeating included a variety of foods; in particular, they ate more sugary foods, high caffeine foods, starchy or fatty foods, and highfat and salty snacks. The sub- theme of "secretive eating" means that participants ate secretly to avoid negative judgments and blame for their overeating, or that secretive eating was to passively eat their share of the food.

Conclusion: The results of this study showed that emotional eating alone is not harmful, but some other experiences that accompany it, cause it to be harmful in physical, psychological, and social dimensions. An interesting finding of this study is the sub-theme of "body abuse". This sub-theme expresses the need for people to maintain their mental cohesion even at the cost of harming their body. Another important point of this study is that; the "harmful companions" of emotional eating that emerged in the form of seven sub-themes complicate the cognition and management of emotional eating, and it is necessary to pay attention to harmful companions in psychotherapy programs to manage emotional overeating especially in women.

Keywords: Phenomenology, Hermeneutic, Lived Experiences, Emotional Eating, Obesity.

\section{Conflict of Interest: No}

How to Cite: Ebrahimi E, Mohammadi Shirmahaleh F, Habibi M, Mardani Hamooleh M. Harmful Experiences Associated with Emotional Eating of Iranian Obese Women: A Phenomenological Study. Iran Journal of Nursing . $2021 ; 34(132): 47-62$.

Received: 12 Jul 2021

Accepted: 11 Oct 2021 


\title{
تجارب آسيب زا در خوردن هيجانى زنان فزون وزن ايرانى: يك مطالعه يديدار شناسى
}

\author{
احترام ابر اهيمى '، فاطمه محمدى شير محله '، مجتبى حبيبى"'، مرجان مردانى حموله
}

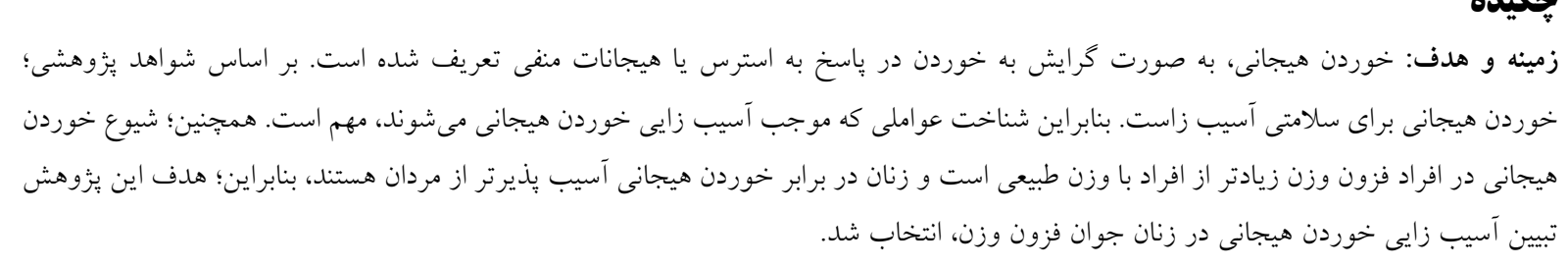

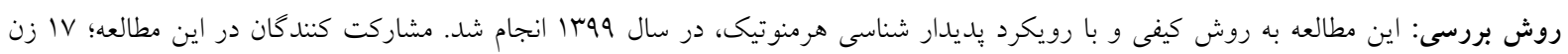

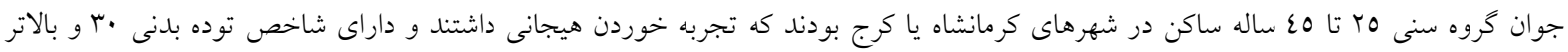

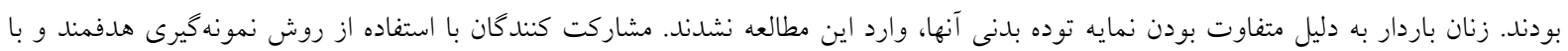

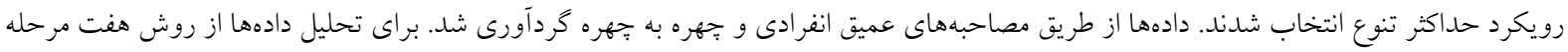
اي Diekelmann و همكاران، استفاده شد.

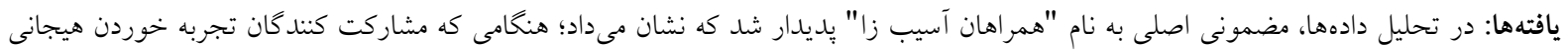

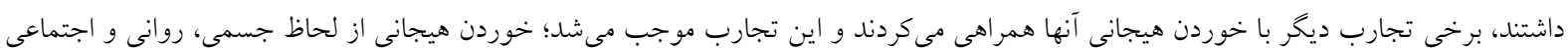

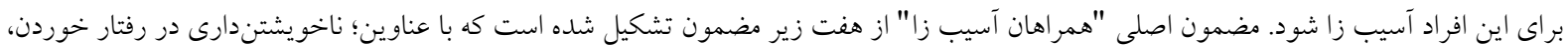

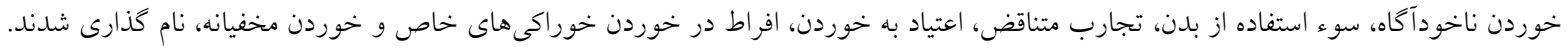

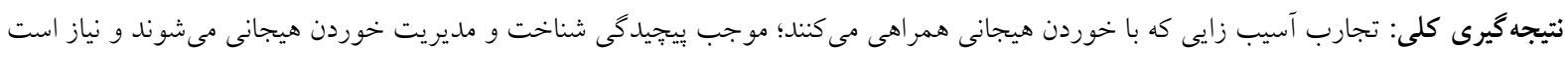

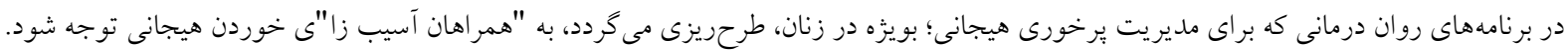

كليد وازهها: يديدار شناسى، هرمنوتيك، تجارب زيسته، خوردن هيجانى، فزون وزنى.

$$
\text { تاريخ دتارض منافع: ندارد }
$$

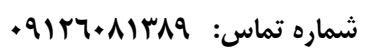

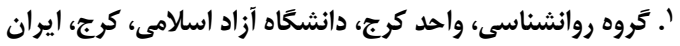

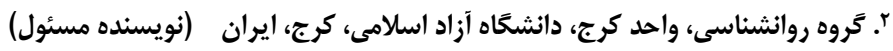

Email: Fatemeh.mohamadi@ kiau.ac.ir "ا. مركز تحقيقات ارتقاء سلامت، كروه روانشناسى سلامت، دانشكده علوم رفتارى و سلامت روان، دانشكاه علوم يزشكى و خدمات بهداشتى درمانى ايران، تهران، ايران

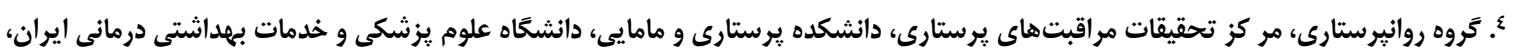
تهران، ايران 
بنابراين يُزوهش كنونى با استفاده از رويكرد يديدار شناسى

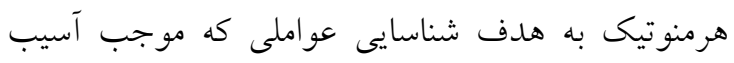

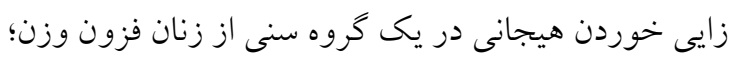

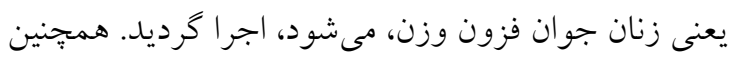
با توجه به اينكه رفتار خوردن هيجانى علاوه بر جهان

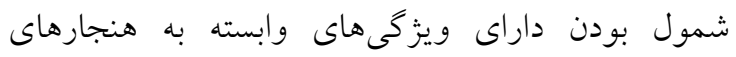

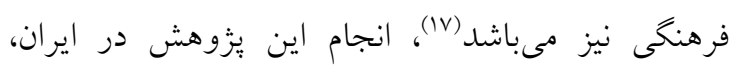

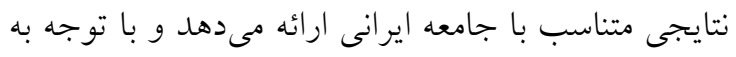

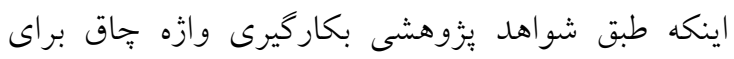
بسيارى از افرادى كه درگير اين وضعيت هستند، فشار بندار

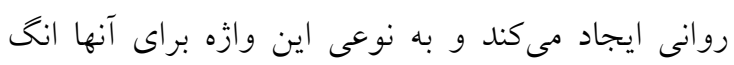

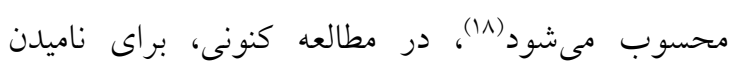

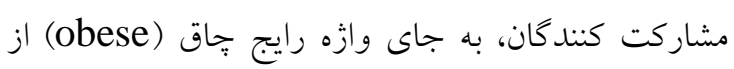

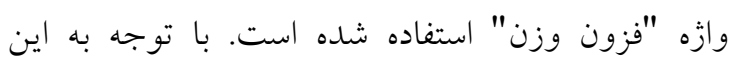
توضيحات، هدف بزوهش كنونى تبيين آسيب زايى خوردن هيجانى در زنان جوان فزون وزن ايرانى بود.

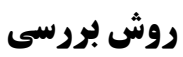

مُزوهش كنونى به روش كيفى و با استفاده از رويكرد بِديدار

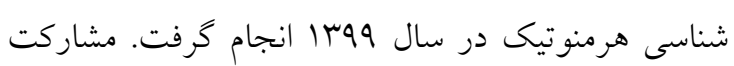

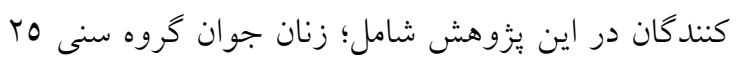
تا هع ساله بودند و به علت دسترسى مصاحبه گرك به زنان

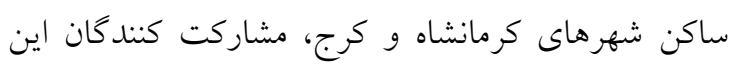

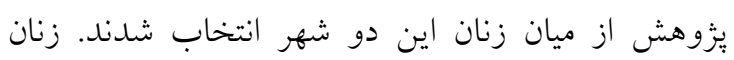

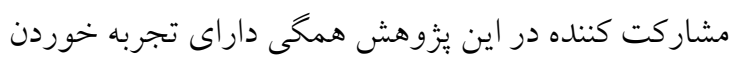
هيجانى و شاخص توده بدنى (Body Mass Index)

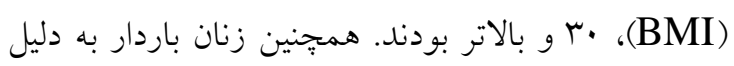
متفاوت بودن نمايه توده بدنى آنها، وارد اين مطالعه نشدند. با توجه به اين توضيحات، نمونه گيرى به شيوه هدفمند

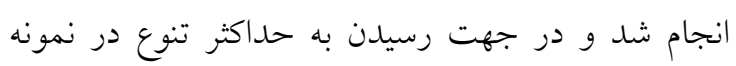

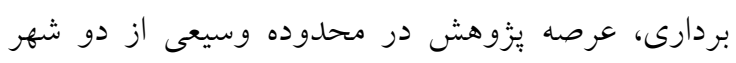

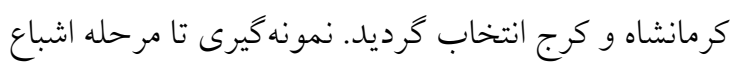

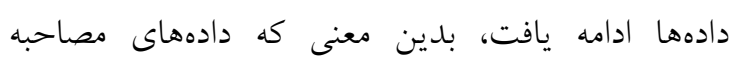

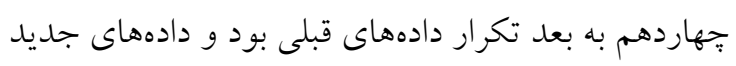

مقدمه خوردن هيجانى (emotional eating)، به صورت كرايش به خوردن در ياسخ به استرس يا هيجانات منفى، به منظور غلبه بر عاطفه منفى تعريف شده است (1). خوردن

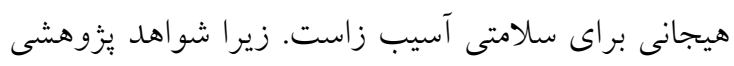
نشان دادهاند؛ افراد همزمان با خوردن هيجانى با تجارب ديخرى از قبيل خودكنترلى ضعيف روى رفتار خوردن(r) و تمايل به خوردن غذاهاى يرجرب، شيرين و پيركالرى(ه-r)

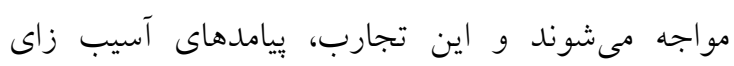
متعددى براى سلامتى افراد دارد. مثلاً افزايش وزن (1.v)، افزايش خطر ابتلا به ديابت نوع دو (^)، بروز سندرم

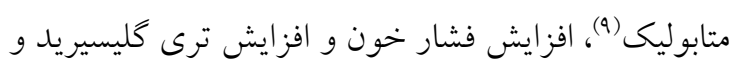

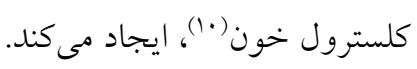
شناسايى دقيق انواع تجارب آسيب زايى كه با خوردن هيجانى همراهى مى كنند، موجب مىشود كه نسبت به خوردن هيجانى و آسيب هاى آن بينش عميق ترى بيدا كنيم

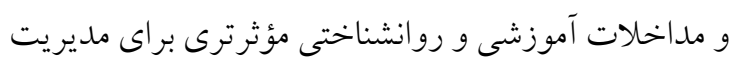
خوردن هيجانى طرح ريزى نماييم. براى رسيدن به اين هدف؛ شناخت عميق رفتار خوردن هيجانى اهميت دارد. براى اين كار، نياز است با وارد شدن به دنياى تجربيات

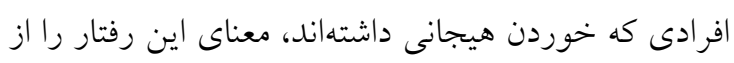
زاويه نخاه آنها كشف نماييم و ابعاد كوناگون روانى، اجتماعى و فرهنكى خوردن هيجانى را در جارجوب تفاسيرى كه افراد بر اساس آن به اين تجربه معنا مىدهند، شناسايى نماييم و بر اساس اين تفاسير و معنادهىها مداخلات آموزشى و روانشناختى را طرح ريزى نماييم. زيرا مداخلاتى كه به نقش اساسى معنادهىها و تفسيرهاى

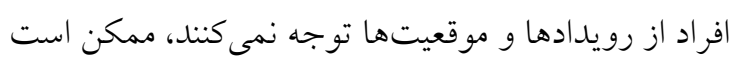
روشى بى حساب و كتاب را در بيش كيرند (1'). يزّوهش

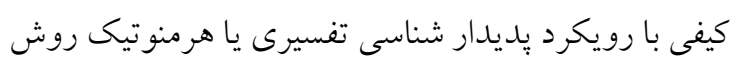
مناسبى براى رسيدن به اين هدف است. با در نظر كرفتن اين توضيحات و اينكه شيوع خوردن هيجانى در افراد فزون وزن زيادتر از افراد با وزن طبيعى است(عا-1ا) و زنان در برابر خوردن هيجانى آسيب يذيرتر از مردان هستند (10,17)؛ 
يادداشتها در مرحله تحليل دادهها استفاده نمود. يُرسش هاى اصلى كه در حين مصاحبه از مشاركت كنند يادان

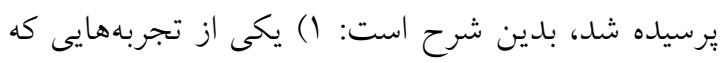
در مورد خوردن هيجانى داشتى، تعريف كن و در مورد

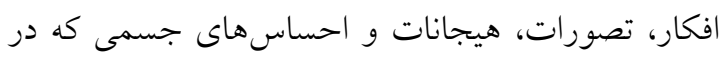
آن موقع شما را به سمت خوردن هيجانى برد، توضيح بده.r) اين تجربه كه تعريف كردى شبيه كداميك از

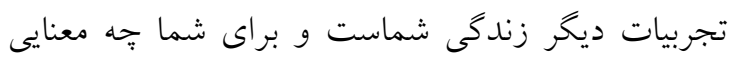

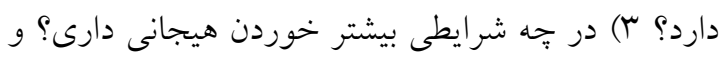
از نظر شما رابطه اين شرايط و خوردن هيجانى به جهن معناست؟ ع) جهه فرقى بين زمانهايى كه خوردن هيجانى رئى دارى و زمانهايى كه خوردن عادى دارى وجود دارد؟ در

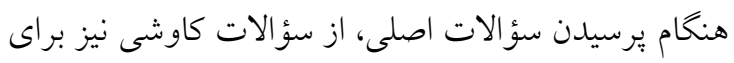
دستيابى به لايههاى عميقتر تجارب زيسته مشاركت

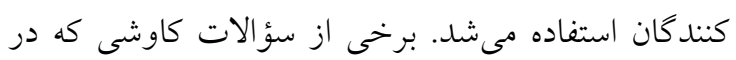
يزوهش كنونى به كار كرفته شد، بدين شرح است:

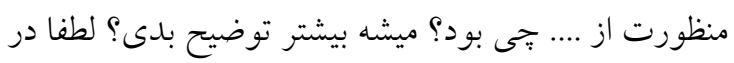

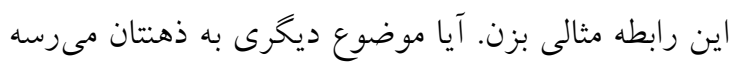

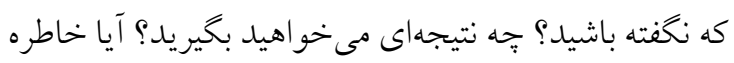

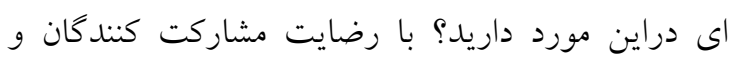
رعايت محرمانه بودن مصاحبهها، متن كامل مصاحبهها ضبط كرديد و در بايان هر مصاحبه از مشاركت كنند مانان قدردانى بعمل آمد. - قدان تحليل دادهها بر مبناى بديدار شناسى هرمنوتيك كه شامل توصيف و تفسير معناى تجارب زيسته مىباشد، انجام كرفت و براى اين كار از روش Diekelmann و و همكاران (19/9) كه فرآيندى هفت مرحلهاى و مبتنى بر

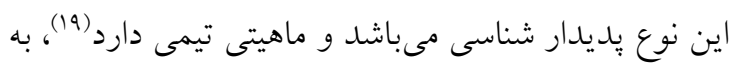
ترتيب مر احل ذيل استفاده شد: در مرحله اول؛ بعد از انجام هر مصاحبه، متن ضبط شده به همراه يادداشتهاى در لرن عرصه، بر روى كاغذ دستنويس مىشد. سبس اين متنها

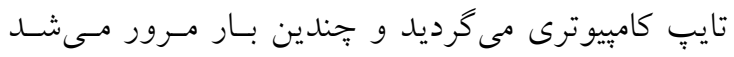

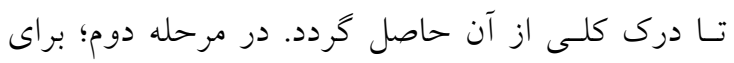

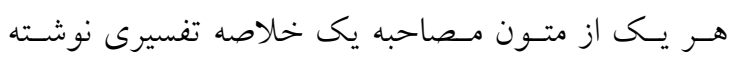

ديخرى بدست نيامد. بنابر اين يس از مصاحبه هفدهم نمونه

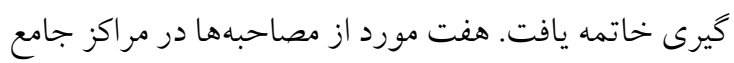

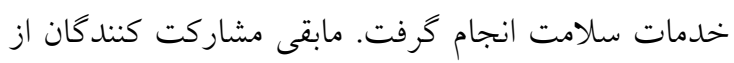

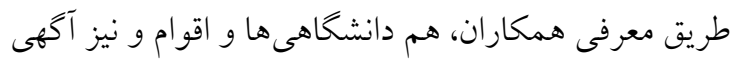

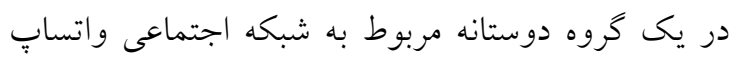
وارد اين مطالعه شدند و اين مشاركت كنندكان در هنخام اجراى مصاحبهها در منزل خود حضور داشتند.

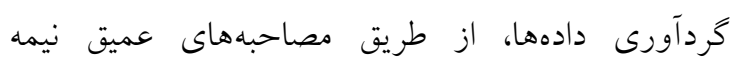

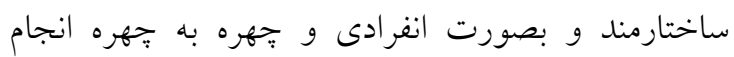
كرفت. همه مصاحبه ها توسط يزووهشخر اول كه در هنخام

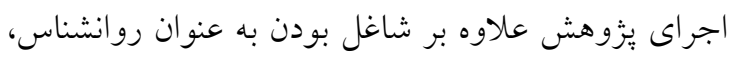

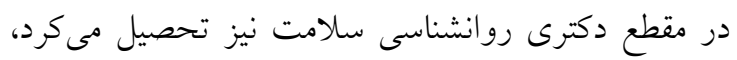

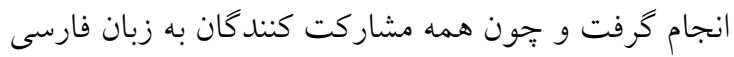
تسلط داشتند، همه مصاحبهها به زبان فارسى انجام كرفت.

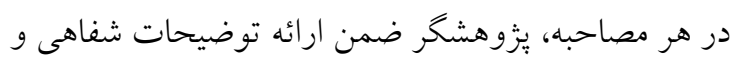

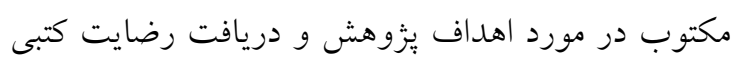
از مشاركت كنندكان، در مورد داشتن حق تصميم گيرى آنان جهت شركت در مطالعه و امكان اعلام انصراف در هر درد دردين مرحله از مطالعه و محرمانه ماندن اطلاعات، اطمينان داد.

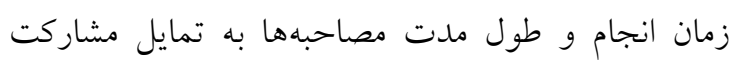

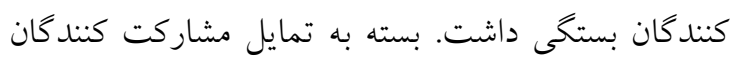

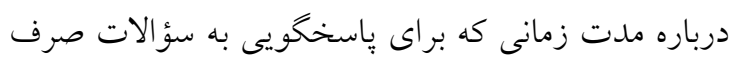

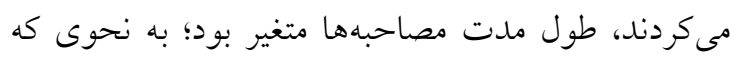

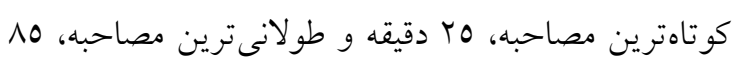

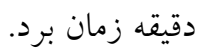

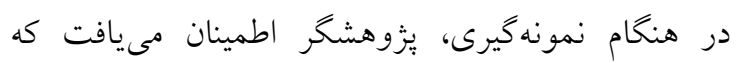

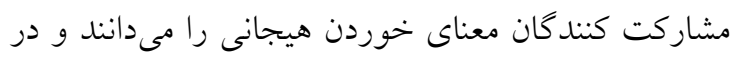
صورت نياز درباره معناى خوردن هيجانى براى آنها توضيح مى داد و در صورت داشتن تجربه خوردن هيجانى و ساير

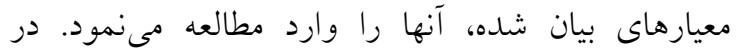
مصاحبهها؛ كَردآورى دادهها از طريق برسيدن سؤ الات باز پاسخ انجام مى گرفت. همجنين بزوهشخر از يادداشتهاى

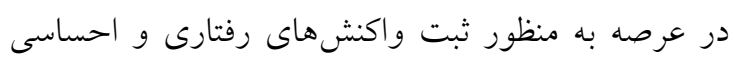

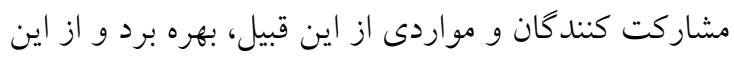


تأييد اينكه درون مايههاى استخراج شده از متن مصاحبه،

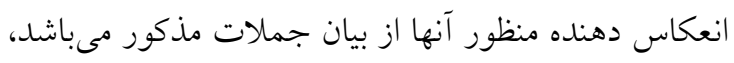

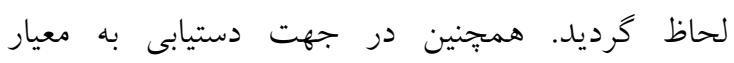

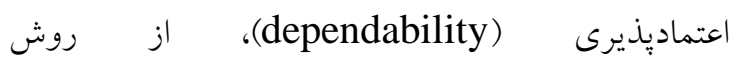
Diekelmann و همكاران كه داراى ماهيت تيمى است، براى تحليل دادهها استفاده شد و مراحل انجام يزوهش و تحليل دادها به روشنى توصيف شد، تا هر خواننده و

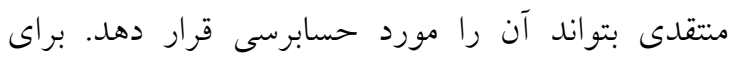
دستيابى به معيار تأييد بذيرى (confirmability) يزوهشكر تمامى دادها و درون مايههاى استخراج شده را

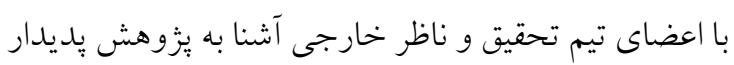

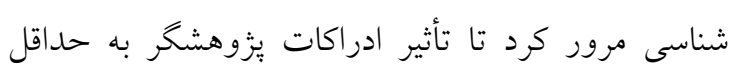

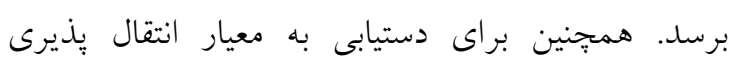

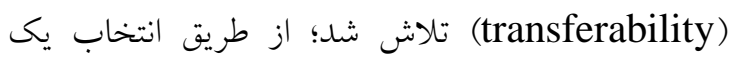
نمونه هدفمند از زنان جوان فزون وزن داراى تجارب

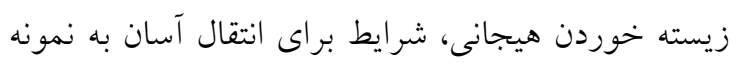

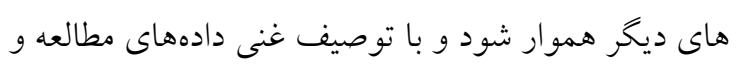

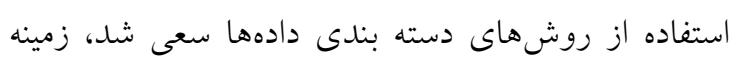

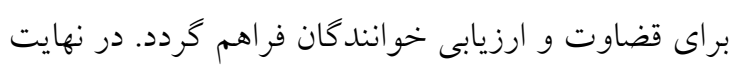

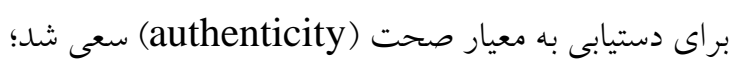
ضبط و نسخهبردارى كفتار مشاركت كنند كان همراه با ثبت

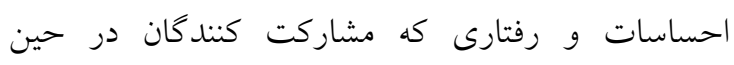

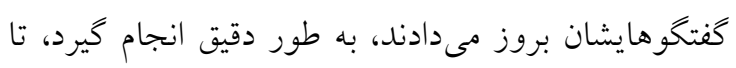
بتوان آوا و نداى احساسات و زندكى مشاركت كنندكان،

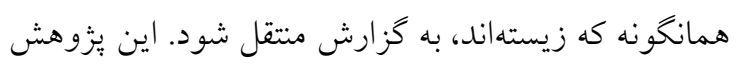

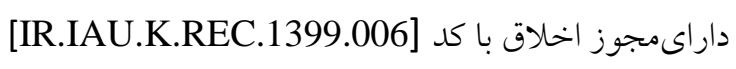

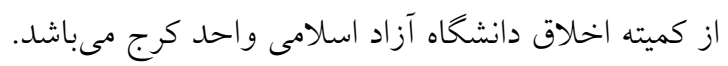

\section{يافتهها}

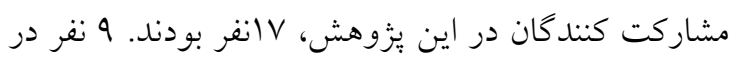

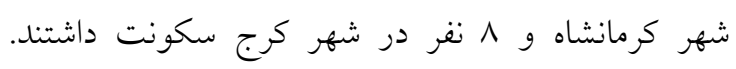
״ايينترين و بالاترين سطح تحصيلات در ميان اين

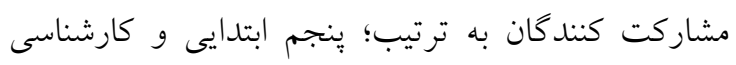

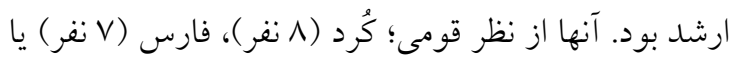

مىشد و نسبت بـه درك و اسـتخراج معسانى نهفتـهـ

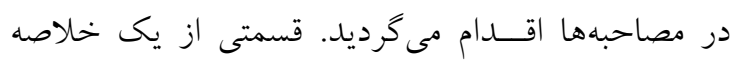
تفسيرى به همراه واحدهاى معنايى استخراج شده از آن،

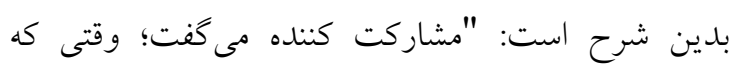

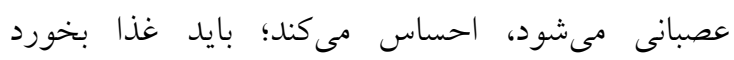
(احساس اجبار براى خوردن). حتى بعضى وقتها كاملاً

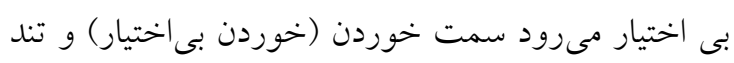

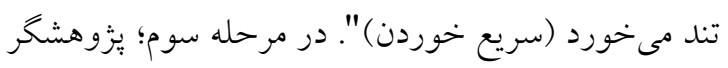
با كمك اعضاى تيم تحقيق درباره واحدهاى معنايى

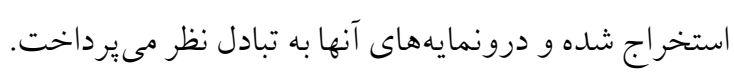

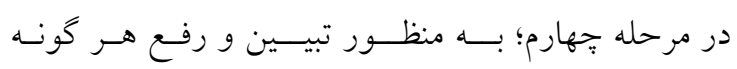

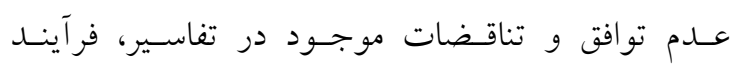

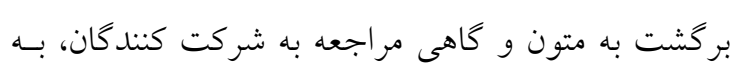

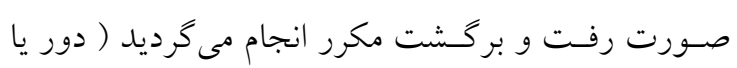

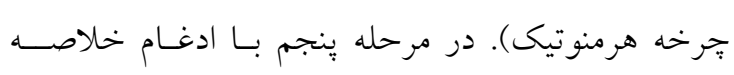

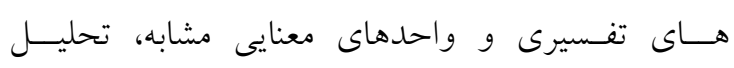

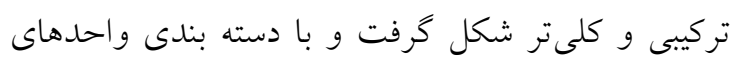

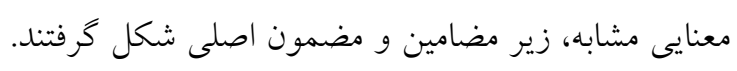

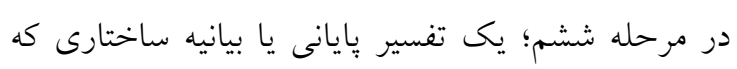

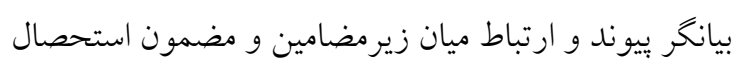

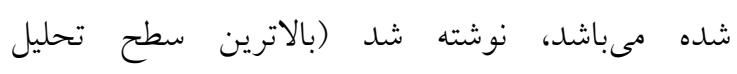

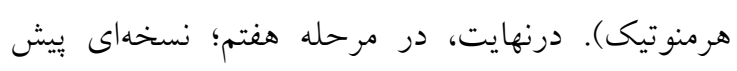
نويس از مضامين و زيرمضامين و منتخبى از متن مصاحبه

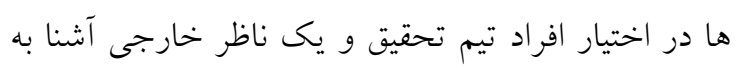

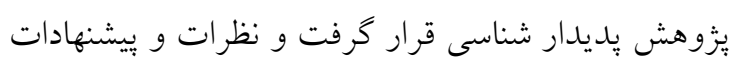
آنها در نسخه بايانى گزارش طرح لحاظ گرديد.

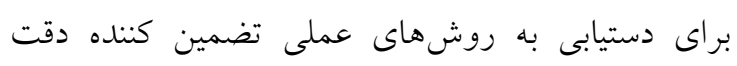
و موثق بودن (rigor)

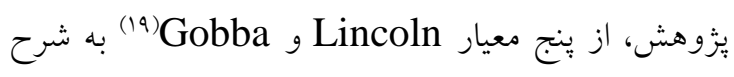
ذيل استفاده شد. مثلاً جهت دستيابى به معيار اعتبار يذيرى معيار

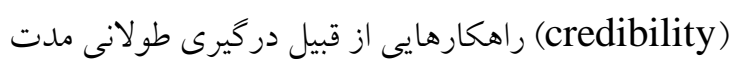

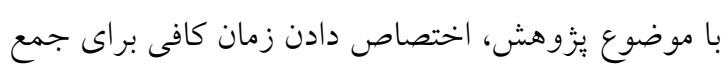

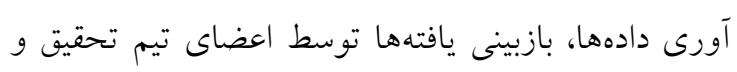

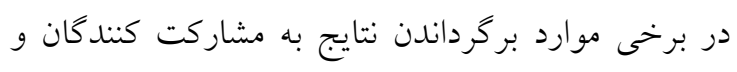


ترى (r نفر ) بودند. ميزان شاخص توده بدنى اين افراد بين

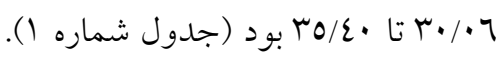

جدول شماره (: مشخصات جمعيت شناختى زنان فزون وزن مشاركت كننده در يزوهش

\begin{tabular}{|c|c|c|c|c|c|}
\hline ميزان نمايه توده بدنى & وضعيت اشتغال & وضعيت تأهل & سطح تحصيلات & سن (سال) & شماره مشاركت كند كًان \\
\hline ri/7. & شاغل & متأهل & كارشناسى & $\varepsilon \varepsilon$ & 1 \\
\hline$r / / 17$ & شاغل & متأهل & زير دييلم & ¿o & r \\
\hline$r \cdot / \mathrm{TV}$ & خانهدار & متأهل & كارشناسى & ¿1 & r \\
\hline m//ro & خانهدار & متأهل & دييلم & $\varepsilon$ & $\varepsilon$ \\
\hline$r \varepsilon / 7$. & خانهدار & متأهل & دييلم & ro & 0 \\
\hline$r 1 / r \varepsilon$ & خانهدار & متأهل & ينجم ابتدايى & $r$. & 7 \\
\hline$r r / 97$ & خانهدار & متأهل & كارشناسى ارشد & $\varepsilon$. & v \\
\hline$r \varepsilon / .7$ & شاغل & مجرد & كارشناسى ارشد & ro & $\wedge$ \\
\hline 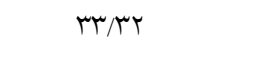 & شاغل & متأهل & كارشناسى ارشد & $\varepsilon \varepsilon$ & 9 \\
\hline$r \cdot / / r$ & خانهدار & متأهل & كاردانى & $r \varepsilon$ & 1. \\
\hline$r \cdot / r$ & خانهدار & متأهل & كاردانى & rV & 11 \\
\hline$r \cdot / \cdot 7$ & شاغل & مجرد & كارشناسى ارشد & rv & ir \\
\hline$r \cdot / \varepsilon r$ & خانهدار & متأهل & كارشناسى ارشد & «o & ir \\
\hline$r \cdot / 11$ & خانهدار & متأهل & كارشناسى & r & $1 \varepsilon$ \\
\hline ro/z. & خانهدار & متأهل & دوم دبير ستان & «o & 10 \\
\hline$r \cdot \mu r$ & خانهدار & متأهل & دييلم & 20 & 17 \\
\hline$r \cdot / \cdot \Lambda$ & شاغل & متأهل & كاردانى & ऍ & IV \\
\hline
\end{tabular}

خوردن، خوردن ناخودآكاه، سوء استفاده از بدن، تجارب

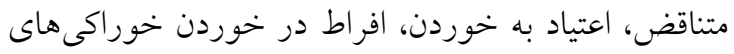
خاص و خوردن مخفيانه. واحدهاى معنايى حمايت كننده از هر يك اين زير مضمونها در جدول شماره r ارائه

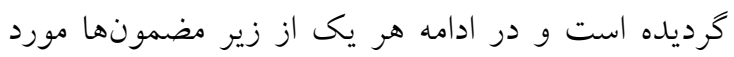
تحليل قرار كرفته است.
طى مصاحبه با اين مشاركت كنندگان، مشخص كرديد؛ برخى تجارب ديخر با تجربه خوردن هيجانى آنها همر اهى مئى مى كنند و اين تجارب موجب مى شوند؛ خوردن هيجانى از

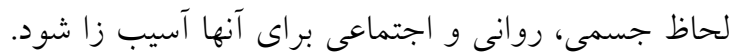

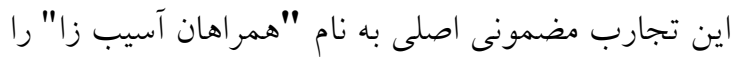

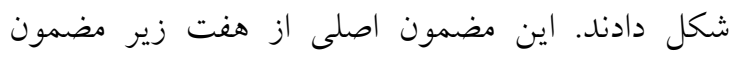
تشكيل شده است كه عبارتند از: ناخويشتن دارى در رفتار

\begin{tabular}{|c|c|}
\hline واحدهاى معنايى حمايت كننده & زير مضمونها \\
\hline سريع خوردن، زياده روى در خوردن، خوردن بى حد و مرز، خوردن با ولع (ولع خوردن)، خوردن ناكهانى، تنوع طلبى در & ناخويشتن دارى در \\
\hline خوردن، خوردن تهاجمى و هول زدن براى غذا، خوردن بدون توجه به كيفيت غذا، قورت دادن غذاى خوب جويده نشده، & 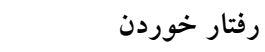 \\
\hline \multicolumn{2}{|l|}{ ريزه خوارى، ميل افراطى به خوردن، حريص بودن نسبت به خوردن، خوردن در زمان نامناسب، گرسنه شدن مكرر، بى } \\
\hline توجهى به عواقب بد خوردن هيجانى، خوردن بدون نياز به غذا. & \\
\hline خوردن بدون ذهن آكاهى (خوردن بدون حضور ذهن)، خوردن بدون اراده، خوردن بى اختيار، خوردن بدون فكر، خوردن & خوردن ناخودآكاه \\
\hline بدون داشتن كتترل روى آن، خوردن بىهدف، خوردن ناخواسته، خوردن بدون حق انتخاب براى خوردن. & \\
\hline
\end{tabular}


زياده روى در ير كردن معده، بى توجهى به يرشدن معده، اذيت شدن معده و روده، خوردن بدون احساس گرسنگى، از سوء استفاده از بدن

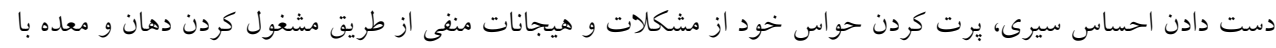

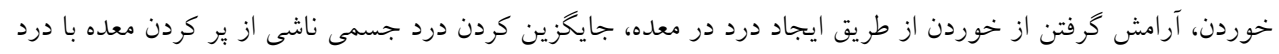

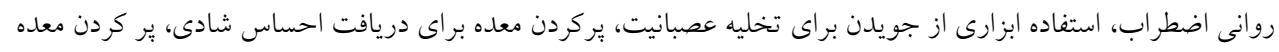

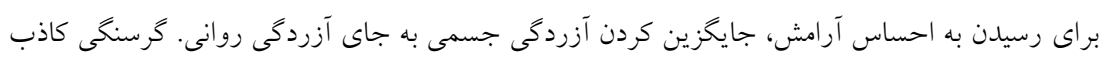

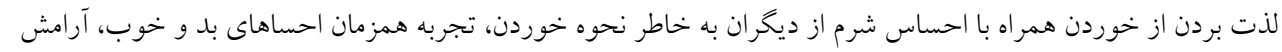
تجارب متناقض

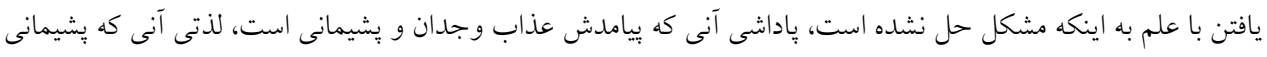

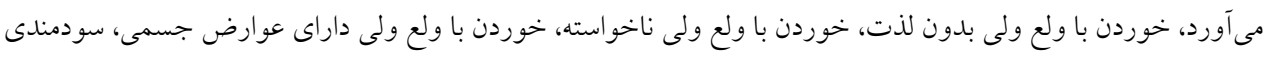

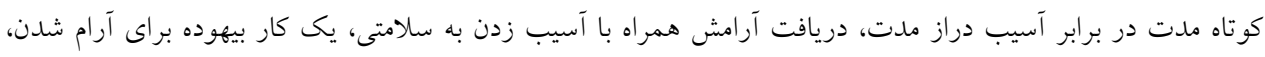

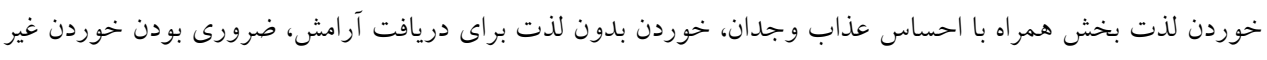

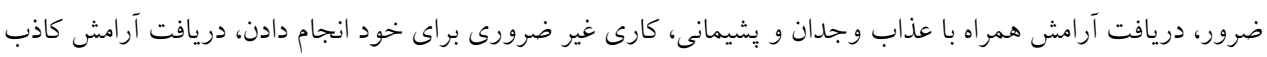

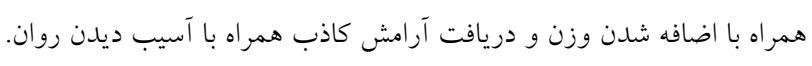

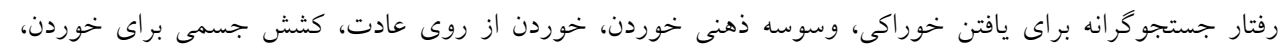
اعتياد به خوردن

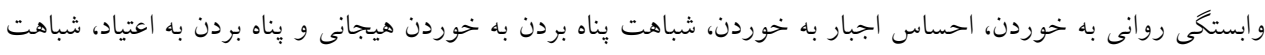

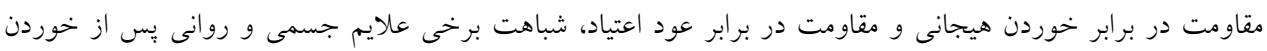
هيجانى با علائم نئشخى مواد مخدر

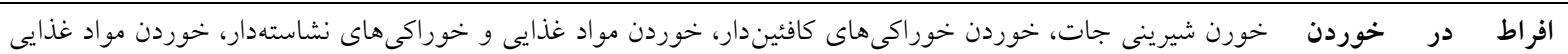
يرجرب، خوردن تنقلات يرجرب و شور خوراكى هاى خاص يِيشخيرى از قضاوت منفى ديخران، ييشخيرى از سرزنش شدن، احقاق منفعلانه سهم خوردن خوردن مخفيانه

كننده (). مثال ديخر درباره ويزگىهاى زياده روى و حريص بودن در خوردن، ولع خوردن و گرسنه شدن مكرر است: "وقتى عصبانى ميشم، بيشتر مى خورم، مثلًً ميخم اينه بخورم، اونه بخورم، با حرص و ولع مى خورم ....... مى بينى يه بشتاب غذا مى خورم ولى دوباره بعلش كرسنه ميشهم. زود به زود كرسنه ميشم" (مشاركت كننده 0). زير مضمون "خوردن ناخود آكاه" زير مضمون "خوردن ناخود آكاه" شامل آن دسته از تجارب همراهى كننده با خوردن هيجانى مىباشد كه در حيطه كنترل ذهن هوشيار نمىباشند و شامل مواردى از قبيل خوردن بدون ذهن آكاهى (خوردن بدون حضور ذهن)، خوردن بدون اراده، خوردن بى اختيار، خوردن بدون فكر، خوردن بدون داشتن كنترل روى آن، خوردن بىهدف، خوردن ناخواسته و خوردن بدون حق انتخاب براى خوردن مىباشد. در اين رابطه يكى از مشاركت كنندگان، يكى از

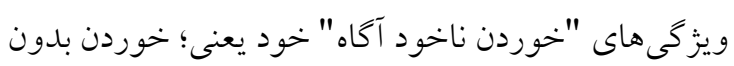
حضور ذهن را اين گونه توصيف مىكرد كه متوجه

\section{زير مضمون "ناخويشتن دارى در رفتار خوردن"} در تحليل صحبت هاى مشاركت كنند گان معلوم گرديد؛ آنها به هنخام خوردن هيجانى، به اندازه كافى روى رفتارهاى مربوط به خوردن، خويشتندار نيستند و خوردن هيجانى آنها همراه با سريع خوردن، زياده روى در خوردن، خوردن بى حد و مرز، خوردن با ولع، خوردن ناگهانى، تنوع طلبى در خوردن، هول زدن براى غذا، خوردن بدون توجه به كيفيت غذا، قورت دادن غذاى خوب جويده نشده، و خوردن در زمان نامناسب است. بر اين اساس يكى از زير مضمونهايى كه در اين بزوهش بدست آمد؛ تحت عنوان

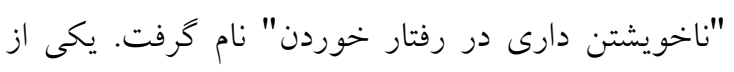
مشاركت كنندگان در بيان تجارب زيستهاش درباره "ناخويشتن دارى در رفتار خوردن" به ويزگى هاى سريع خورن، خوردن بى حد و مرز و زياده روى در خوردن اشاره كرد: "وقتى هيجانى مى خورم، تناتتر مى خورم. كارى ندارم

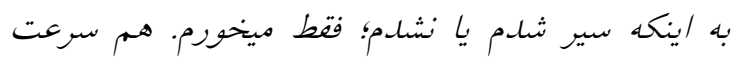
خورنم زياده و هم مقدار خورذنم زياد هست" (مشاركت 
بعل /ز اون برخورى حواسم ميره به سمت /ون احساس

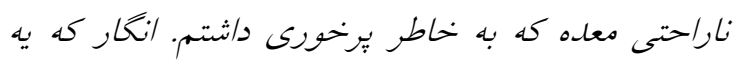

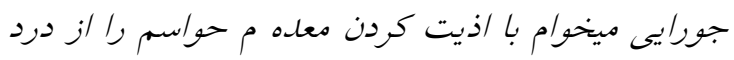

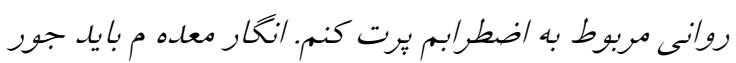
دردهاى روانى من رو بكشه" (مشاركت كننده r ا). " آدم

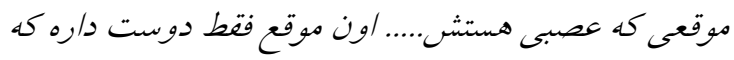

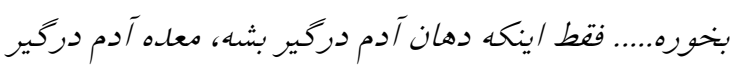
بشه و در حال خوردن باشه؛ شايد ذهن را يه كم آرام كنه،

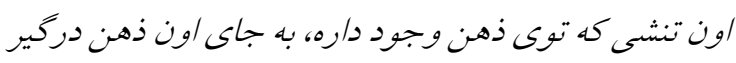

جويدن بشه" (مشاركت كننده • (1).

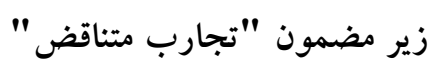
زير مضمون "تجارب متناقض" شامل كاركردهاى دوسويه

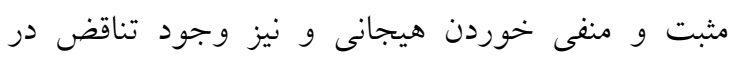

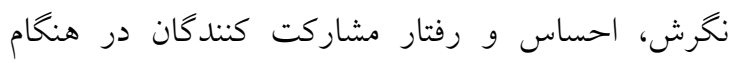

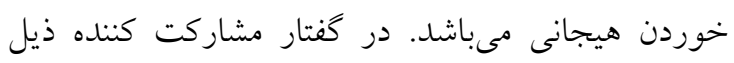

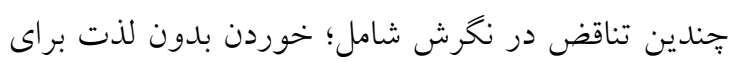
دريافت آرامش، ضرورت دار بودن خوردن غير ضرور و

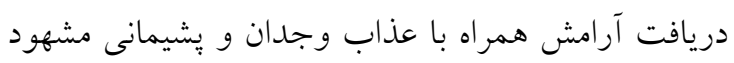

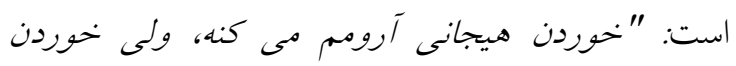

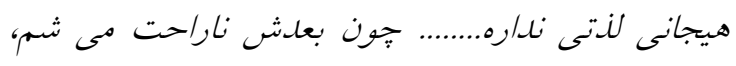

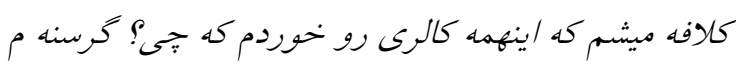

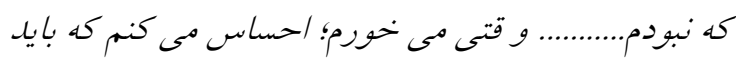

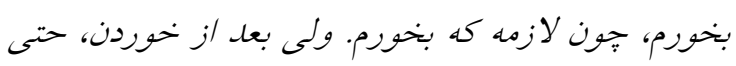

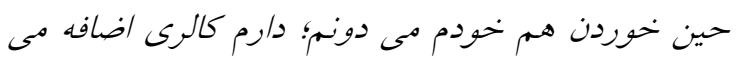
كيرم. ولى بعلش يشيمون ميشم ديكه " (مشاركت كننده

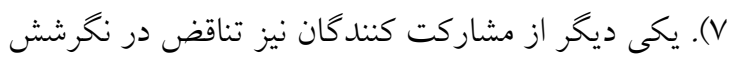
درباره خوردن هيجانى را در قالب "كارى غير ضرورى دئن

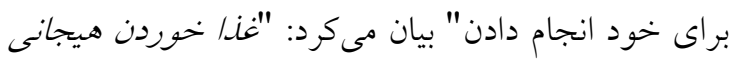

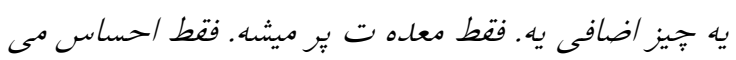

كنم براى خودم كارى كردهم" (مشاركت كننده (). زير مضمون "اعتياد به خوردن" در تحليل كفتههاى مشاركت كنندگان، مشاهده شد؛

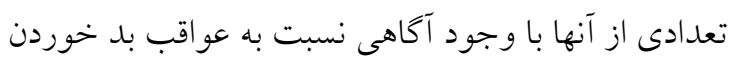

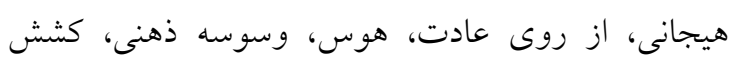

خوردنش نيست و نمىداند كه جى مىخورد، جه مقدار خورده است و جّه موقع سير شده است، به عبارتى اين

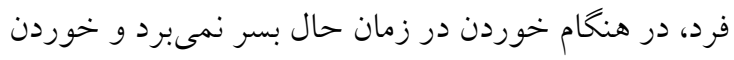

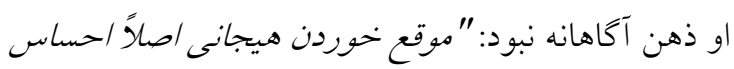

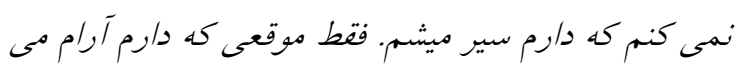

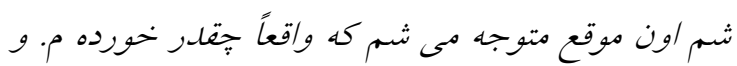

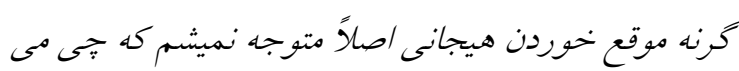

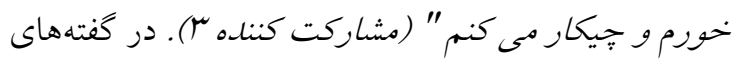

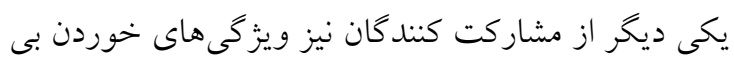

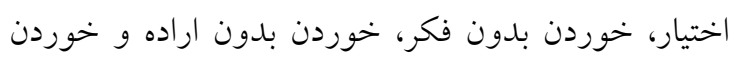

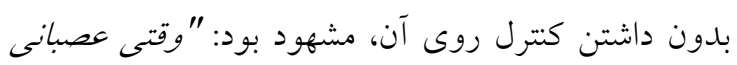

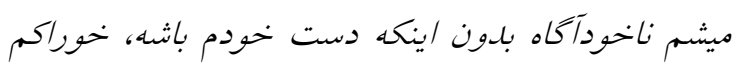

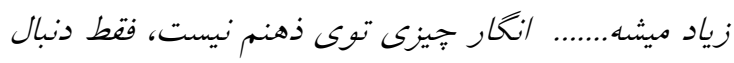
اينم كه با يه راهكارى سريعتر /ون عصبانيت رو كم كنم

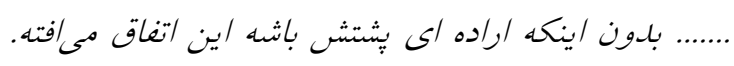

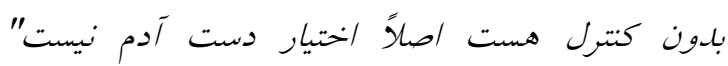
(مشاركت كننده 9). البته مواردى نيز كزارش مى شعد كه با وجودى كه مشاركت

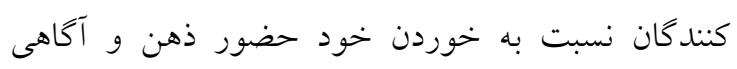

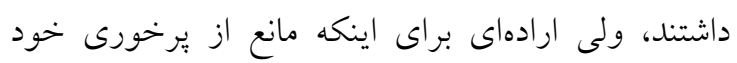

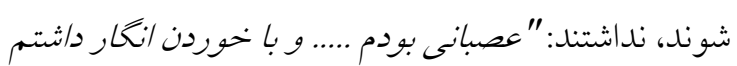

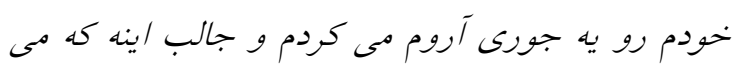

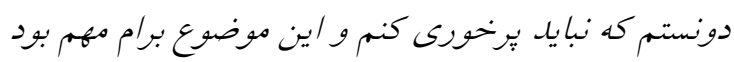

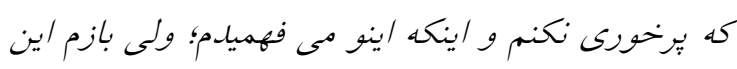
كار رو كردم" (مشاركت كنناه 7 (1) . زير مضمون "سوء استفاده از بدن"

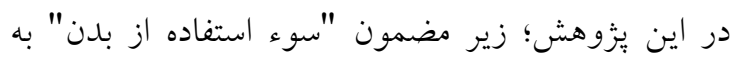

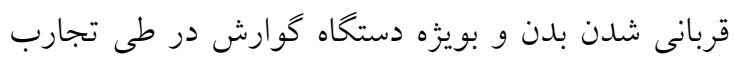

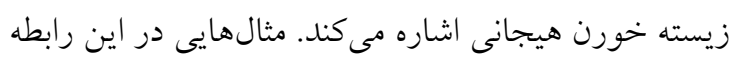
به شرح ذيل است: "مواقعى كه سطح استرسم خيلى سلى

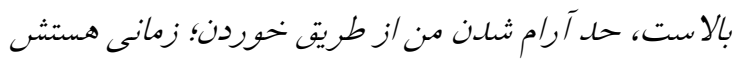

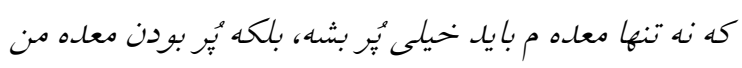

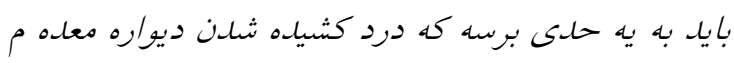

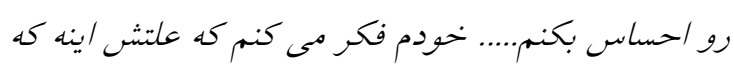


(مشاركت كننده r|). "خوردن آرامم مى كنه. عصبانيت و

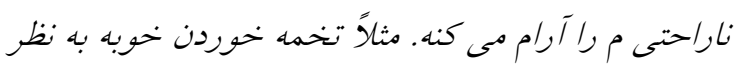

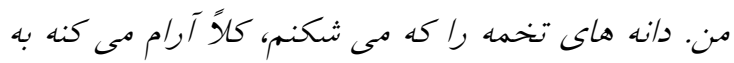

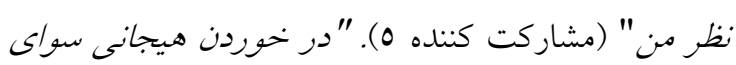

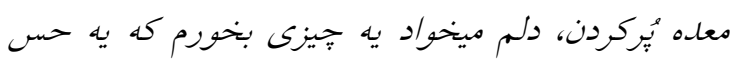
خوب بهم بلده، مثلاً بستنى " (مشاركت كننده ع (1).

\section{زير مضمون "خورردن مخفيانه"} طبق كفتهاى مشاركت كنندكان يكى ديخر از تجارب

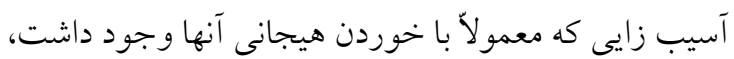

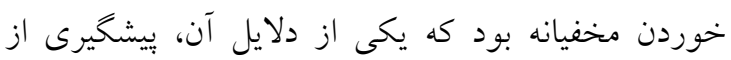
قضاوت منفى و سرزنش شدن توسط اطرافيان بابت

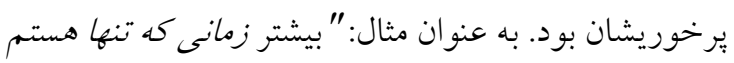
خوردن هيجانى دارم. دوست ندارم يشت سوم بكَن كه زياد ميخوره" (مشاركت كننده ع) (). علت ديخر خوردن مخفيكيانه،

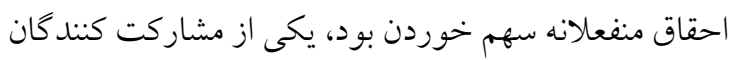

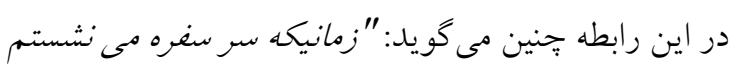

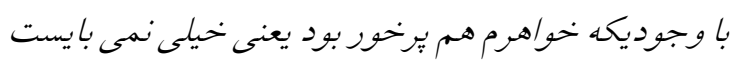

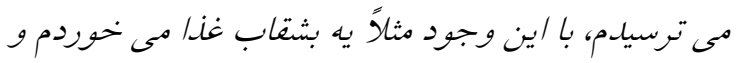

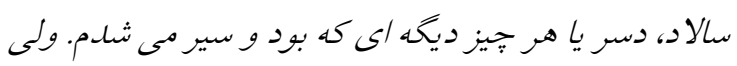

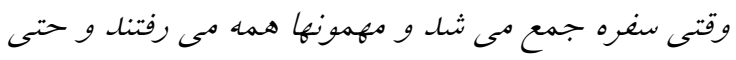

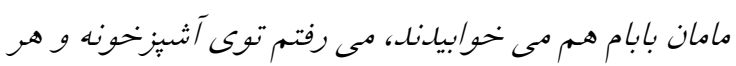

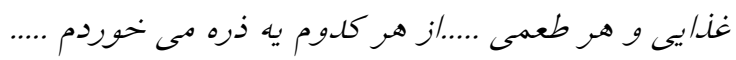

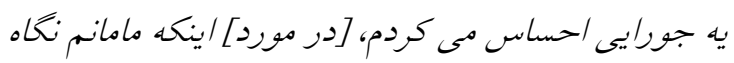

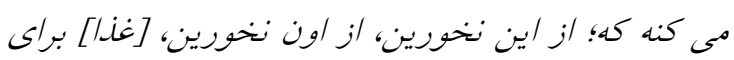
مهمونهاست، با اينكار انكار يه جورى حق خحدم رو كرفته

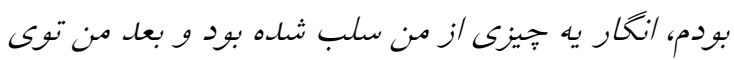
تاريكى مى رفتم كه سهم خودم رو بكيرم (مشاركت كننده

بيانيه ساختارى: از آنجايى كه تفسير يزوهشكر در

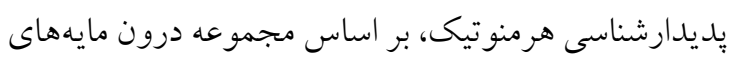

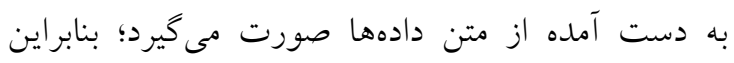

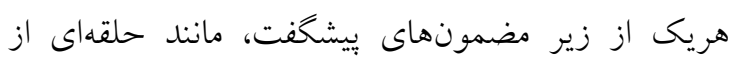

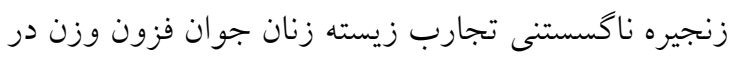

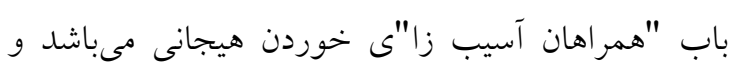

جسمى و احساس اجبار به خوردن هيجانى مى يرداختند و

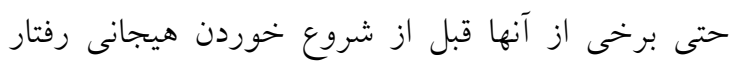

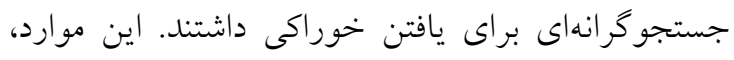

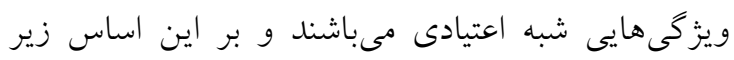

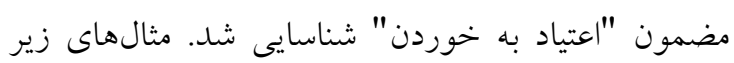
نمونههايى از كفتههاى مشاركت كنندكان درباره وسوسه ذهنى خوردن؛ خوردن از روى عادت و احساس اجبار براى

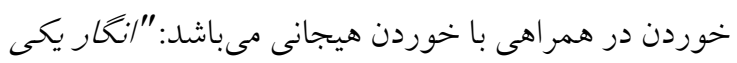

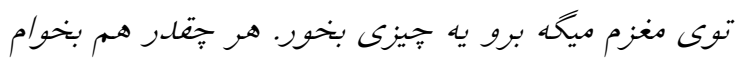
اهميت ندهم، ولى باز هم نمى تونم" (مشاركت كننده Y I ).

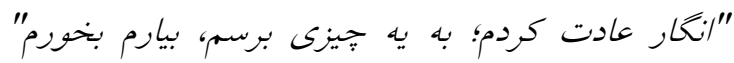

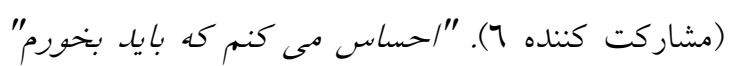
(مشاركت كننده V). يكى از مشاركت كنندكان نيز علائم

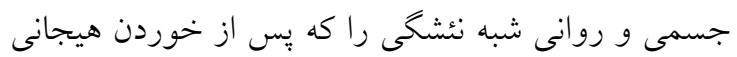

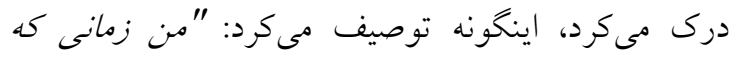

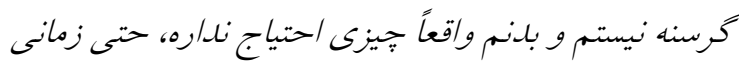

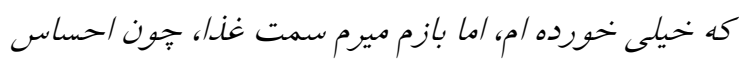

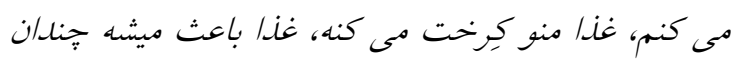

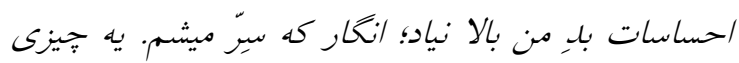

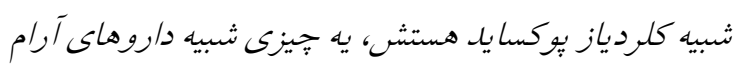
بخشه" (مشاركت كننده A).

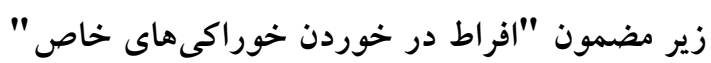
تجارب زيسته مشاركت كنندكان نشان داد؛ با وجودى كه

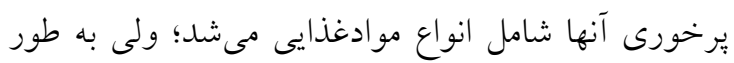
خاص، موادى همجون شيرينى جات، خور اكى هاى كافئين

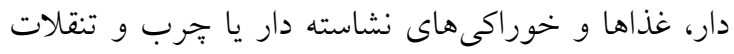

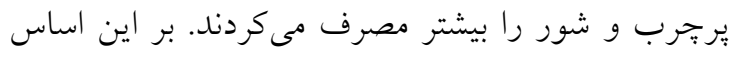
يكى از تجارب همراهى كننده با خوردن هيجانى با عنوان

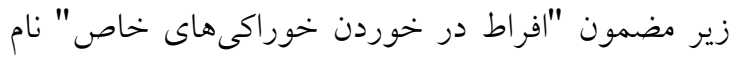

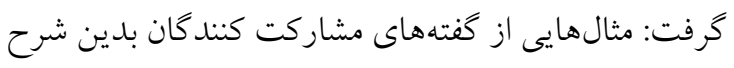

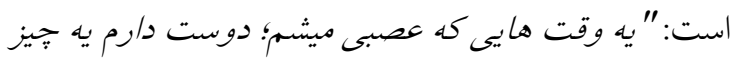

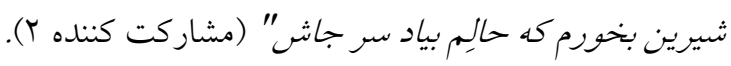

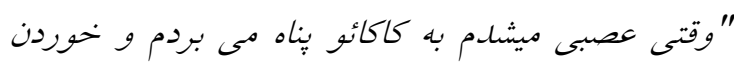

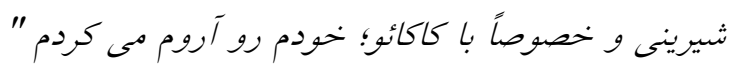


بحث و نتيجه كيرى

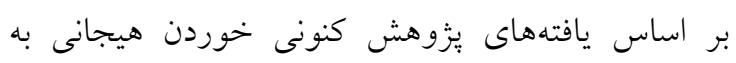

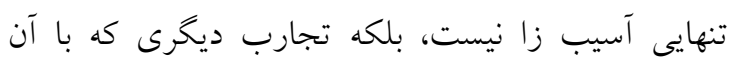

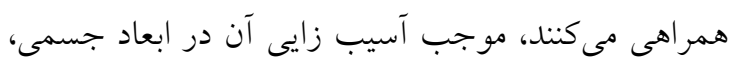

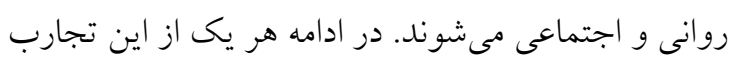

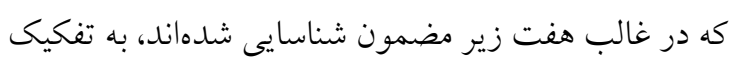

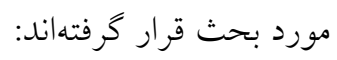

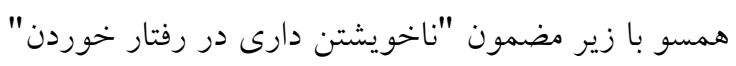

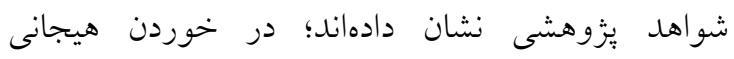
خودكنترلى روى رفتار خوردن ضعيف است (r). طبق نتايج

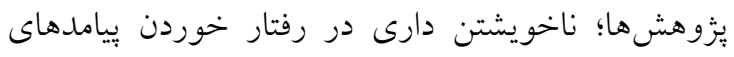

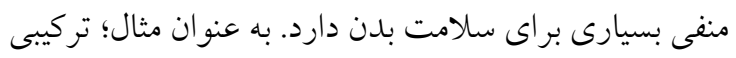

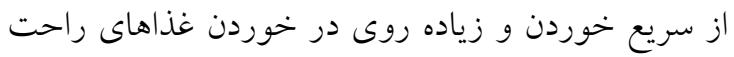

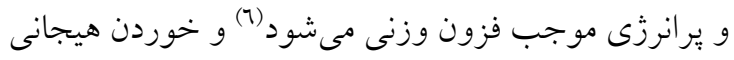

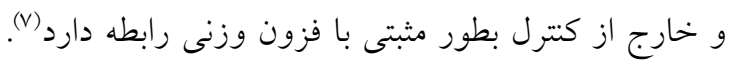

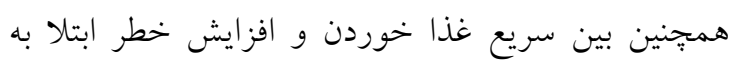

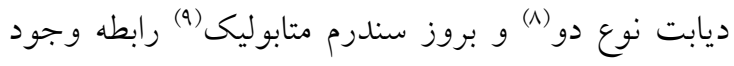

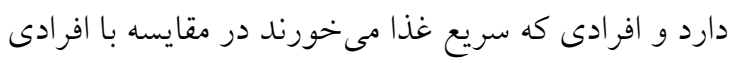

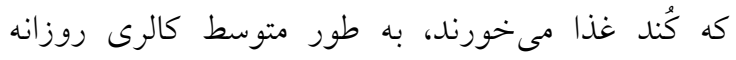
بيشترى مصرف مى كنند، اندازه دور كمر بيشترى دارند،

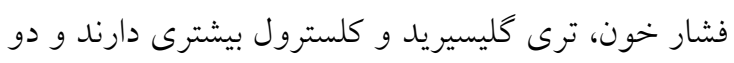

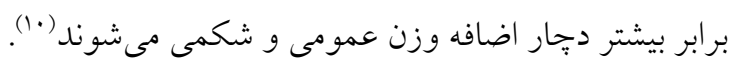

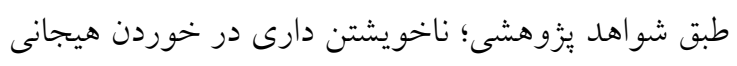

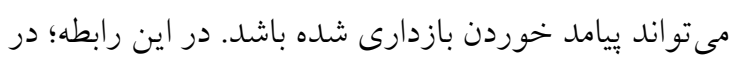

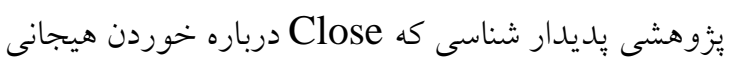

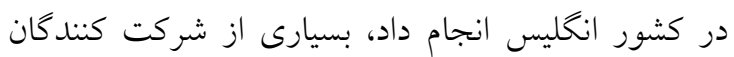

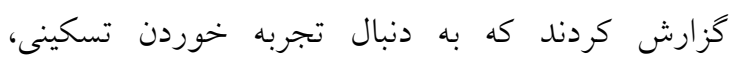
محدوديتهاى غذايى را براى رزيمهاى غذايى خود اعمال مى كردند. محدوديتهاى خوردن باعث مىشد، شركت

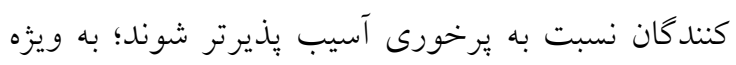

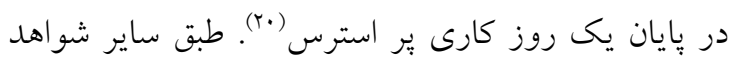

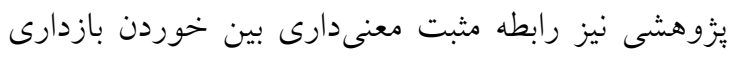

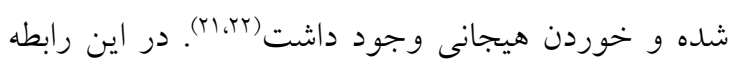

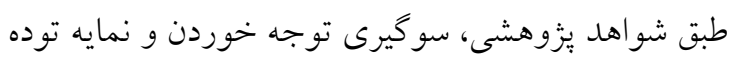

بيوند آنها با هم، به اين نقش معناى عميق بخشيده است.

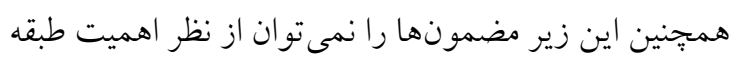

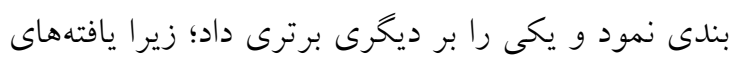

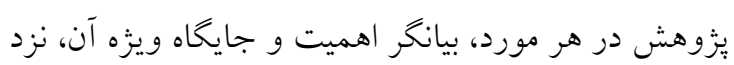

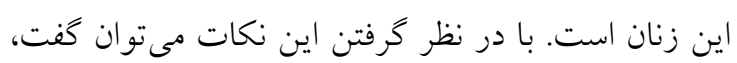

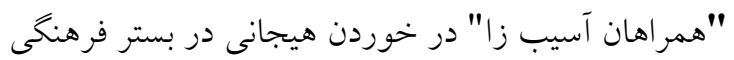
و اجتماعى كشور ايران و بر اساس تجارب زيسته زنان

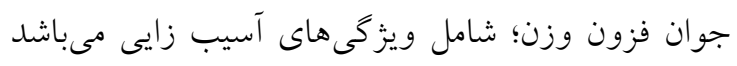

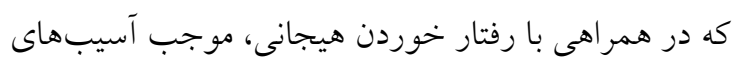

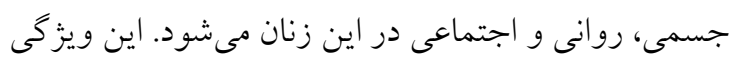

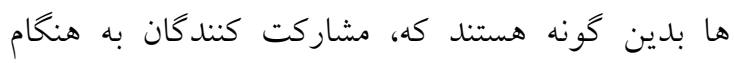

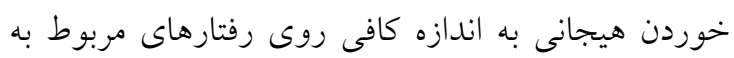
خوردن، خويشتندار نيستند و خوردن هيجانى در حيطه

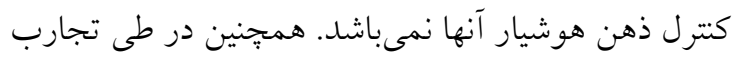

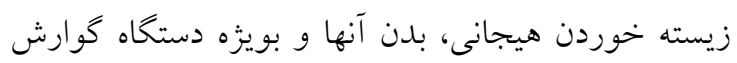
شان قربانى مىشود تا آنها انسجام روانىشان ران را حفظ نمايند و در عين حال آنها در طى خوردن هيجانى، تجارب انهاب

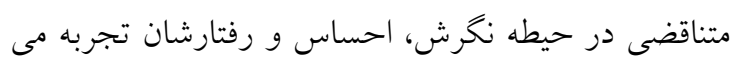

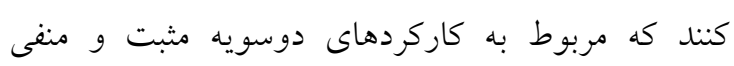

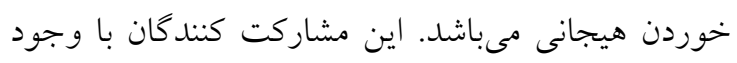

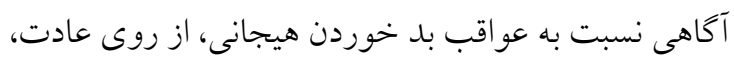

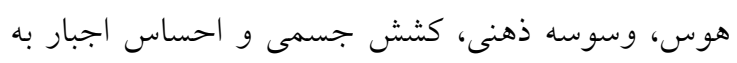

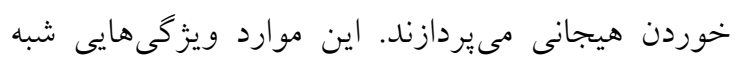

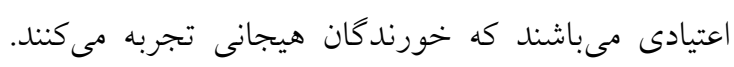

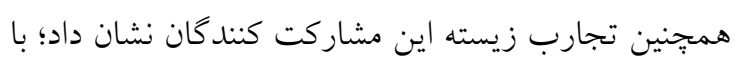

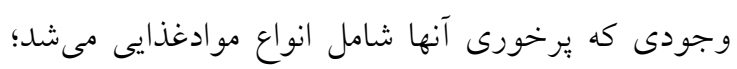

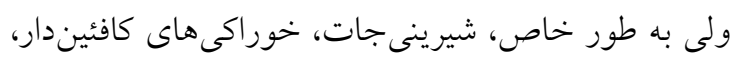

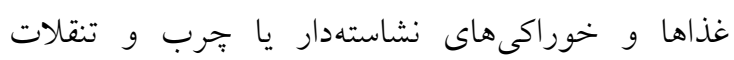

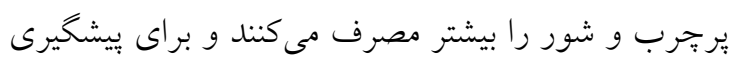

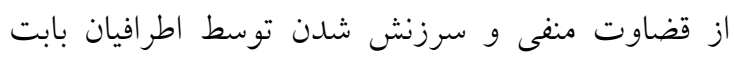

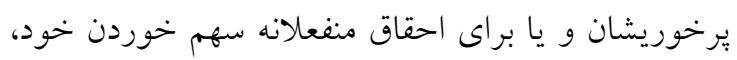
به خوردن مخفيانه روى مى آورند. 
كه در نتيجه در ايجاد رفتارهاى غذايى سالم به آنها كمى مى كند (TV) همسو با زير مضمون "سوء استفاده از بدن" يززوهشى يافت

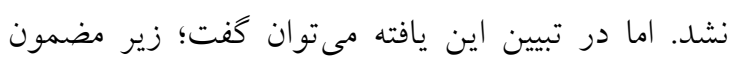

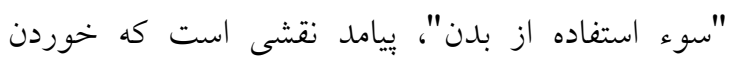

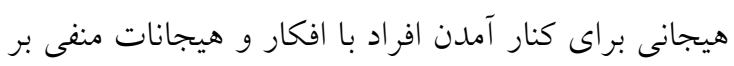

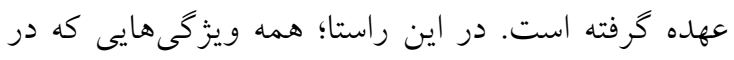
قالب زير مضمونهايى از قبيل "ناخويشتن دارى در رفتار

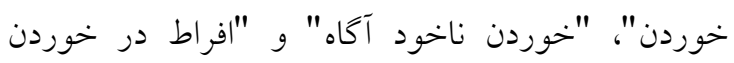

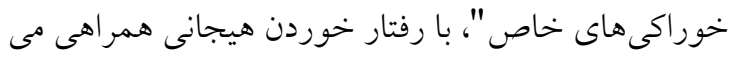

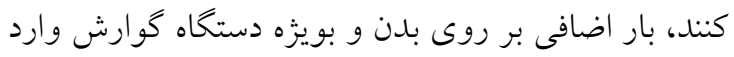

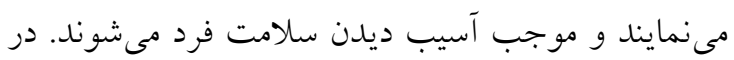

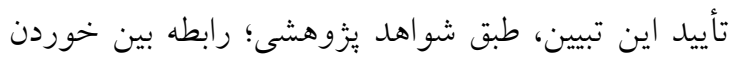
هيجانى با علايم ريفلاكس حلقى - حنجرهاى معنىدار (r^) همسو با زير مضمون "تجارب متناقض"، يكى از زير

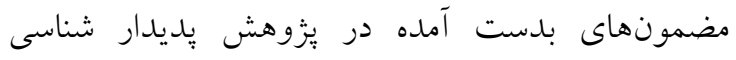
"نlose كزارش شده از يك نبرد ذهنى درونى از افكار ايجاد كننده

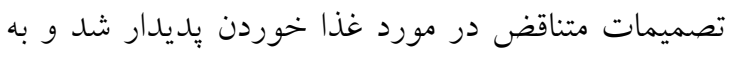

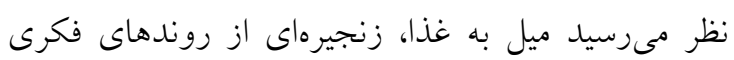
مخالف بيرامون خوردن يا نخوردن را راه اندازى مىكرد. در اين يزوهش، شناخت متعارض حول تصميم براى

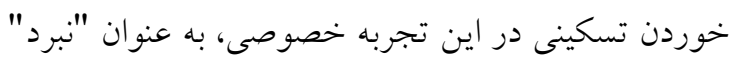

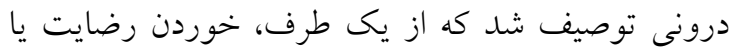

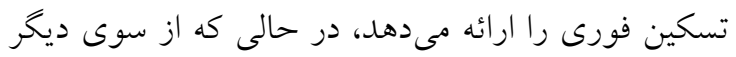
انتقادى و مجازات كننده است(·r). به همين ترتيب؛ Ellis و نيز در يافتهاى يزوهشى خود دركيرى شناختى را بييدا كردند كه در آن شركت

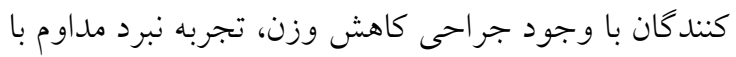

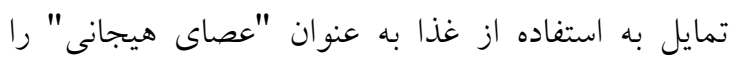

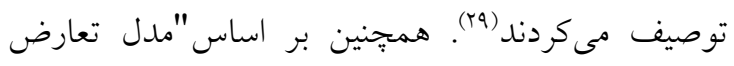
هدف در خوردن لذت طلبانه"؛ خوردن هيجانى با استفاده

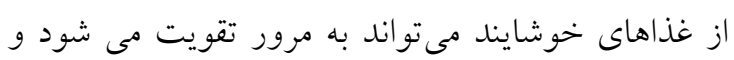

بدنى در رزيم گيرند كان، بيش از افراد عادى است و افرادى

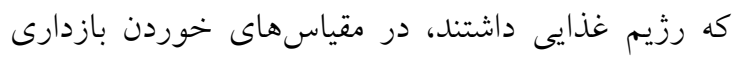

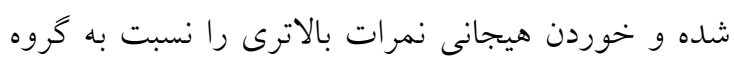
عادى كسب كردند. بدين معنى كه رزيم گرفتن مى تواند باليا

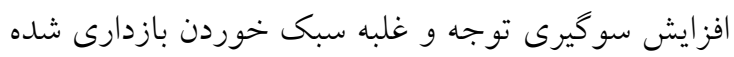

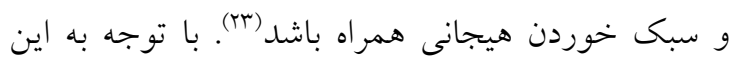

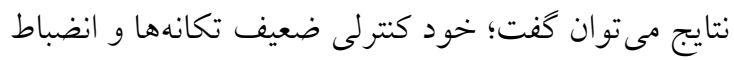
شخصى يايين در خوردن ناشى از هيجانات منفى، اشاره به

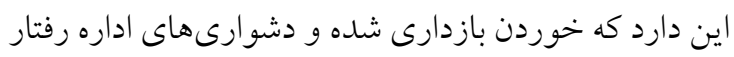

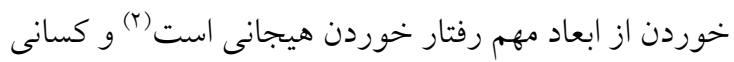
كه مصرف غذا را محدود مى كنند بيشتر احساس "عصيان

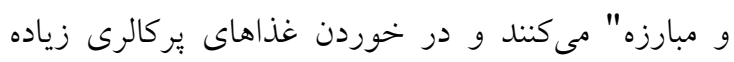
روى مى كنند، در حالى كه افرادى كه عدم بازدارى دارند،

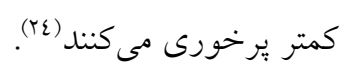

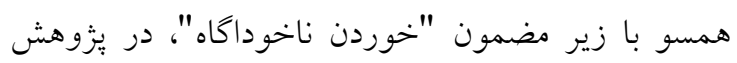

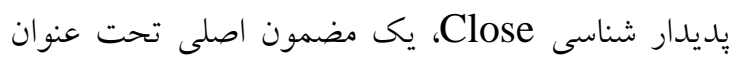

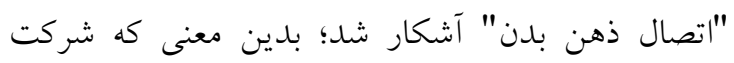

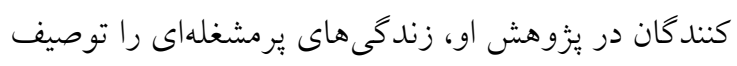

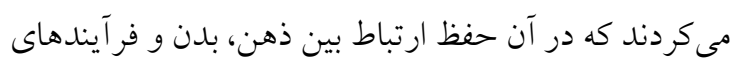

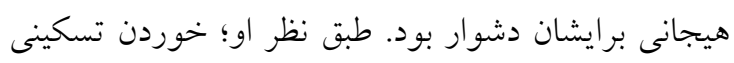

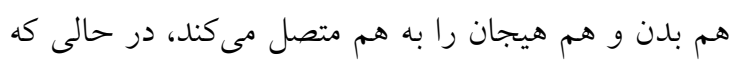

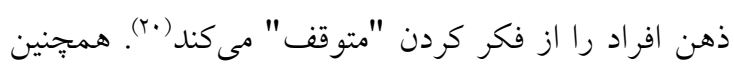

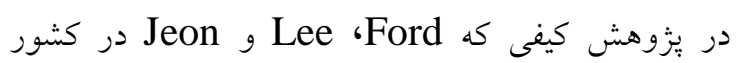

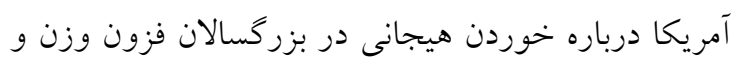

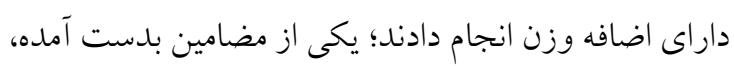

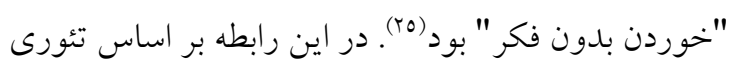

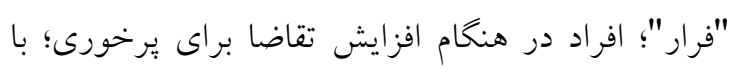

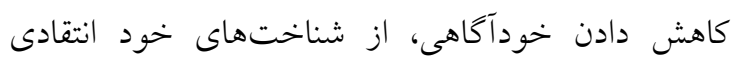

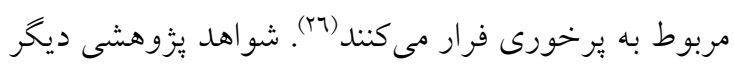

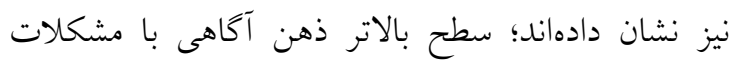

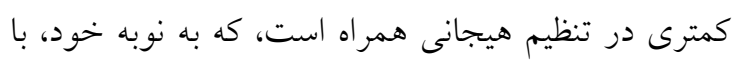

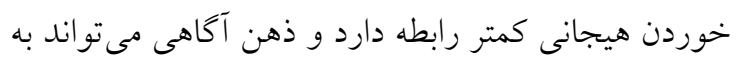

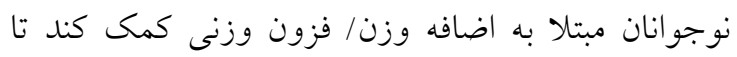
و اكنش هاى ساز گارتر نسبت به يريشانى عاطفى ايجاد كنند، 
به فردو نه ماده خارجى (غذا يا ماده) معطوف كرد و تمركز بر رويارويى با مشكل فزون وزنى بايد از غذا دور شود ماده

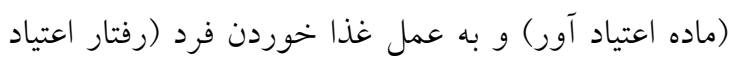

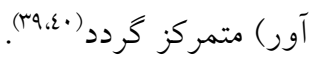
همسو با زير مضمون "افراط در خوردون خردون خوراكىهاى خاص"؛ در يزّوهشى كيفى كه در كشور آمريكا درباره خوردن هيجانى و تجارب مرتبط غذايى منفى در بزر گسالان فزون وزن و داراى اضافه وزن انجام شده بوده،

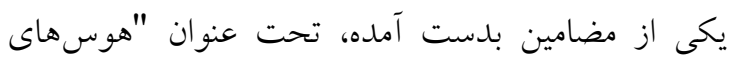

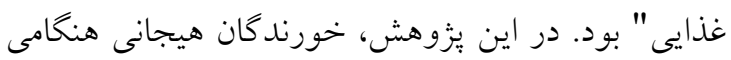
كه در معرض رفتار خوردن هيجانى قرار مى گرفتند، تمايل داشتند؛ به سمت غذاها و طعمهاى خاص كر ايش بيدا كنند و در جستجوى يكى غذاى خاص باشند تا بتواند به آنها

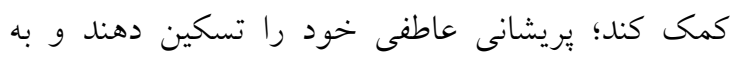

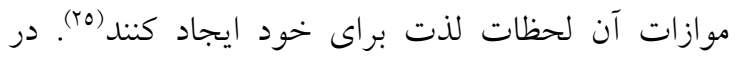

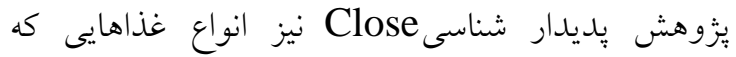
شركت كنند كان هنگام خوردن هيجانى مى خور ردند؛ معمولاً

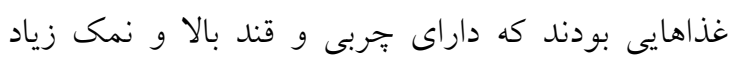

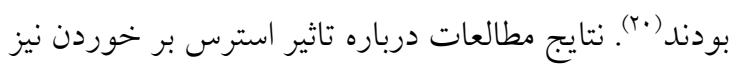

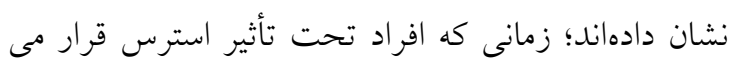

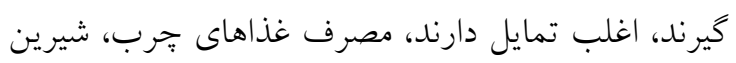

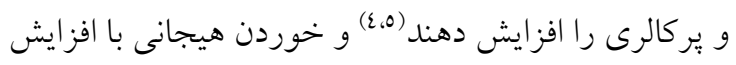

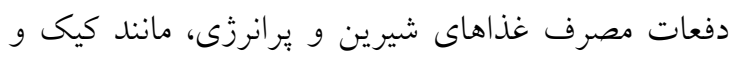

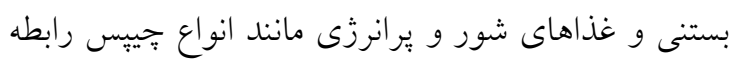

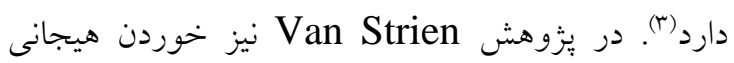

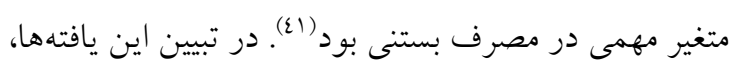
Close

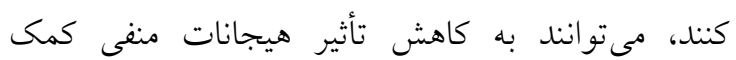

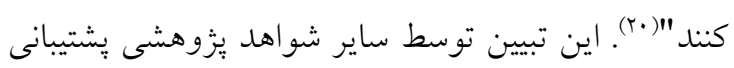

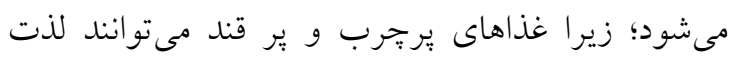

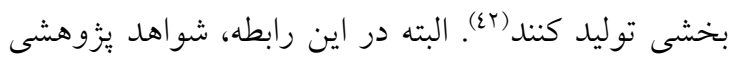

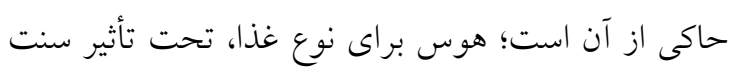

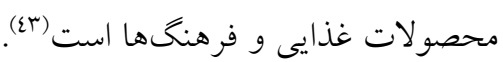

در اين رابطه؛ افراد داراى افزايش وزن، بين دو هدف

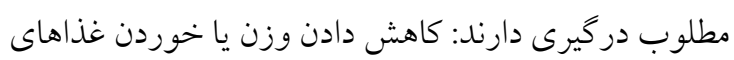

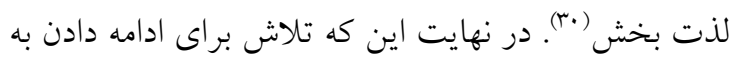
افكار متضاد با خوردن غذا باعث خستكى افراد مىشود و

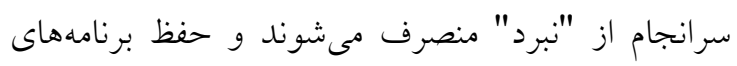
كاهش وزن دشوار مىشود (r.).

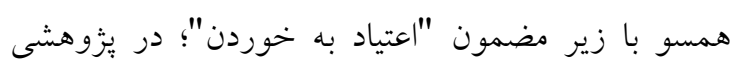

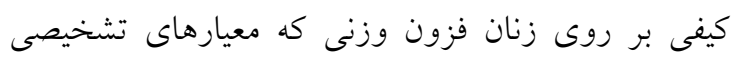

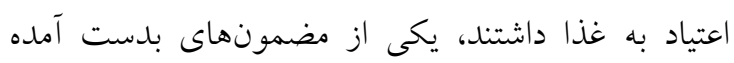
تحت عنوان "حضور خوردن هيجانى" نام كرفت (rان.

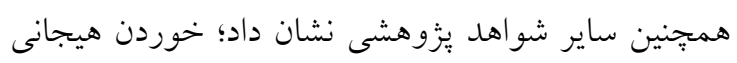

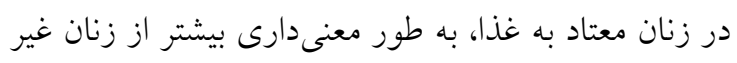
معتاد به غذا است (rr). به نظر مىرسد؛ به تنظيم هيجانى كليد

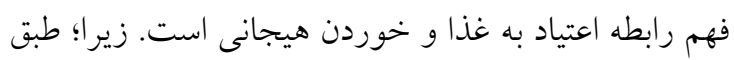

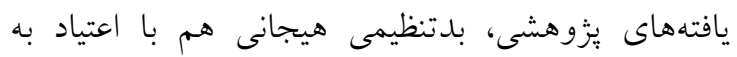

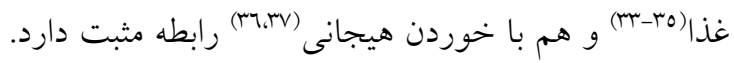
البته در يزوهشى ناهمسو با يافتهاى يزّوهش كنونى؛ اعتياد

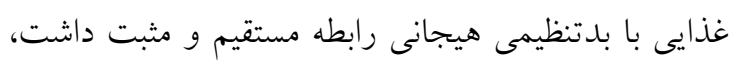

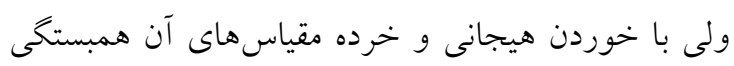

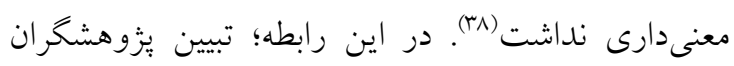
يزّوهش مذكور اين بود كه، خوردن هيجانى بديدهاى كوتاه

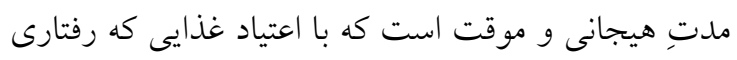

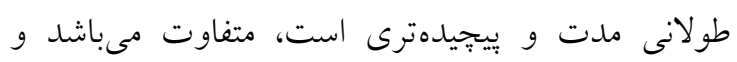

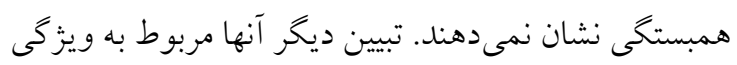

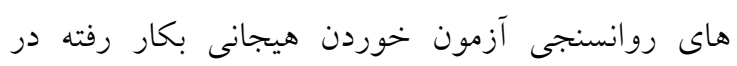

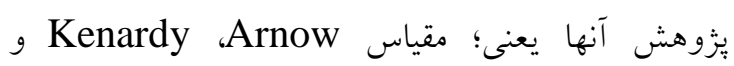
Agras

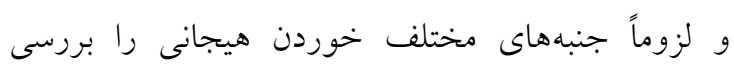

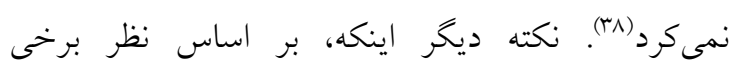

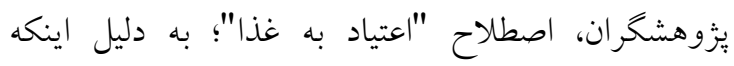

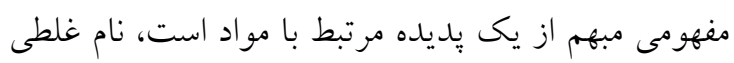

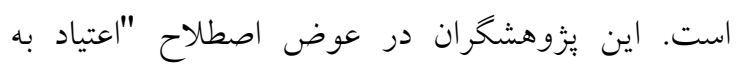

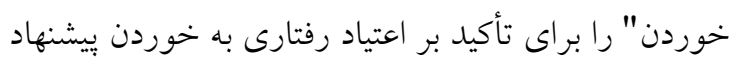

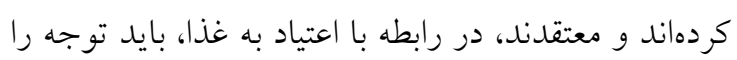


احساس شرم را به همراه داشت، زيرا موجب مىشد آنجه را كه شركت كنندكان از آن فرار مىكردند، بيشتر توليد

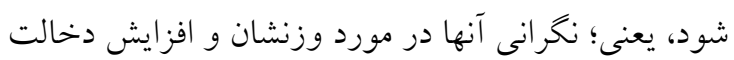

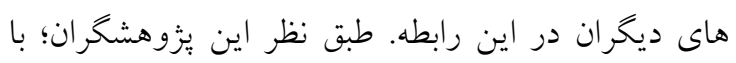
وجودى كه شركت كنندكان از خوردن مخفيانه به عنوان

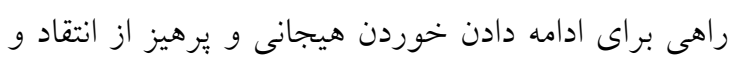

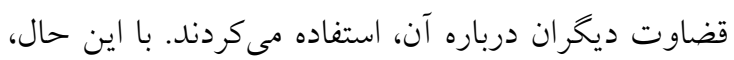

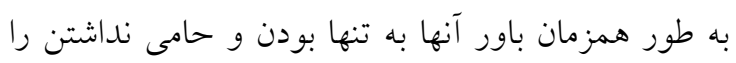

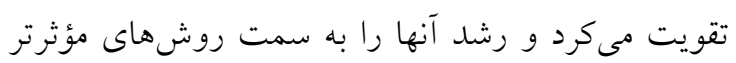
كنار آمدن، محدود مى كرد (ع).

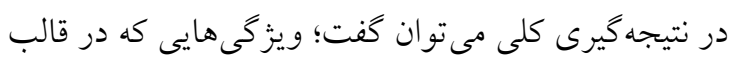

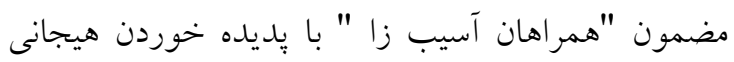

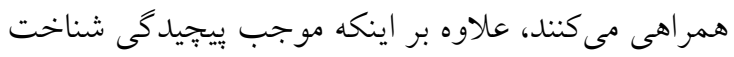

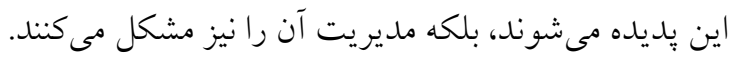

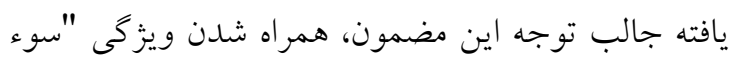
استفاده از بدن" با رفتار خوردن هيجانى مى باشد كه بيانگر

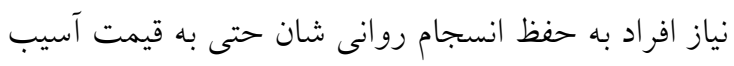

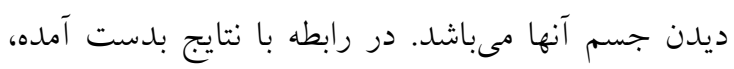

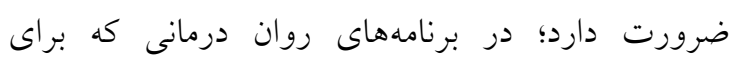
يرخورى هيجانى و مديريت وزن؛ بويزه در زنان، طرح

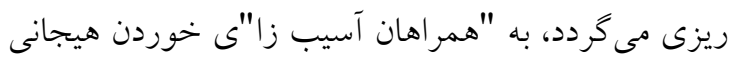

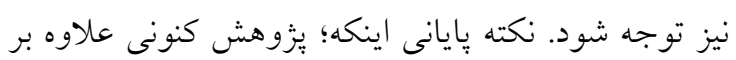

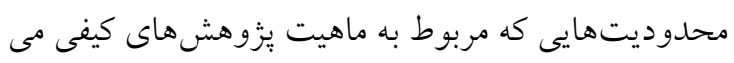

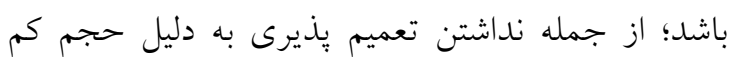

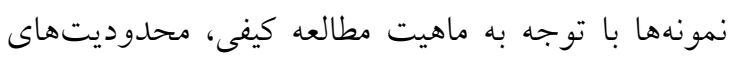

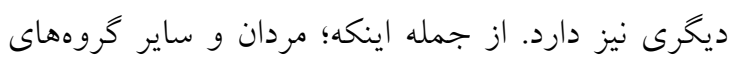
سنى زنان را لحاظ نكرده بود و يُشنهاد مى گردد اين محدوديتها در يزوهش هاى آينده رفع گردد.

تعارض منافع: هيج گونه تعارض منافع توسط نويسندكان بيان نشده است.
همسو با زير مضمون "خوردن مخفيانه"؛ در يُزوهش

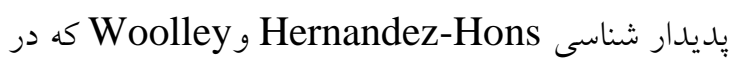
كشور آمريكا درباره خوردن هيجانى انجام كرفت، نيمى از

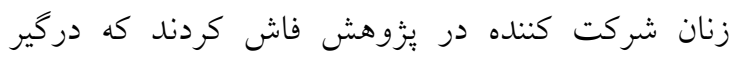

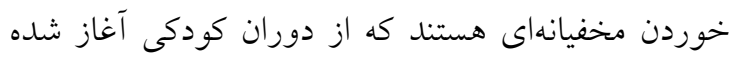

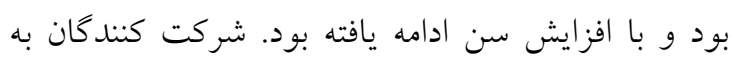

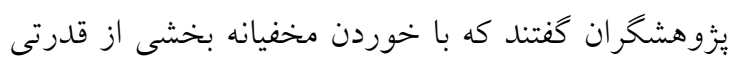

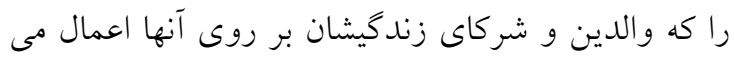

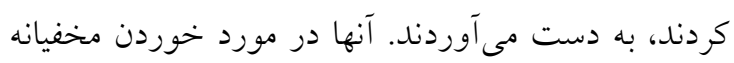
به عنوان نوعى عصيان و راهى براى خروج از بريشانى

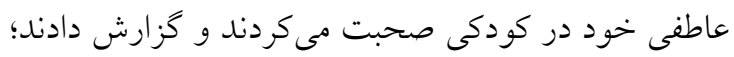
اكنون در بزركسالى، "خوردن مخفيانه"، به روشى تبلى تبديل شده است كه خوردن هيجانى خود را ينهان كنند و از انتقاد

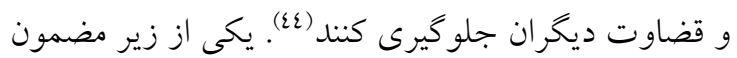

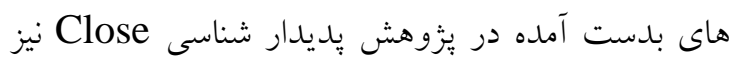

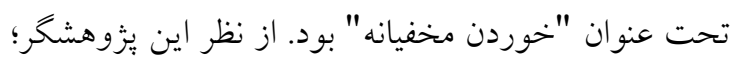

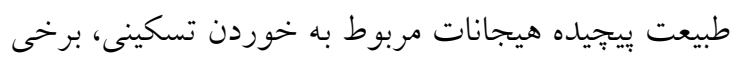
از شركت كنندكان را مجبور مىكرد كه آن را از ديخران

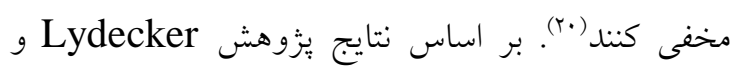

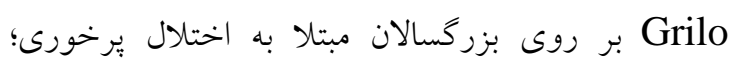

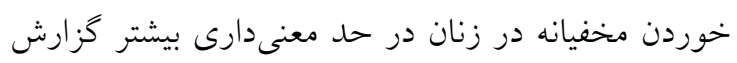

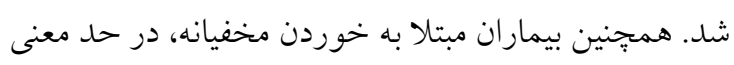

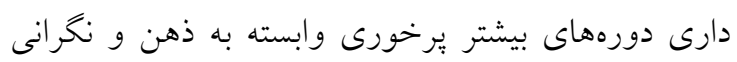

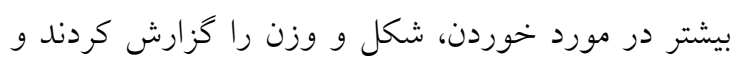

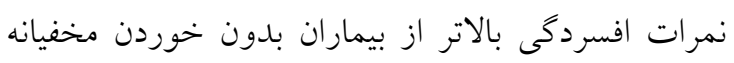
داشتند و در حد معنىدارى بيش از بيمارانى كه خوردن

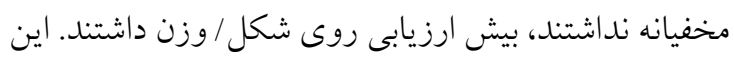
يزوهشگر ان به اين نتيجه رسيدند كه، در ميان بيماران مبتلا

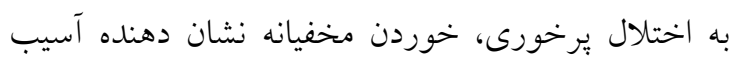
شناسى روانى بيشتر در اختلال خوردن است (20). در رابطه لئه

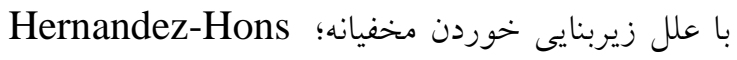

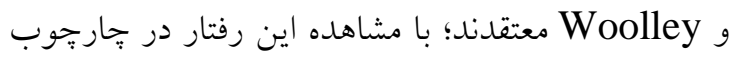
دلبستكى ناايمن، خوردن مخفيانه بهتر درى مىشود. اين

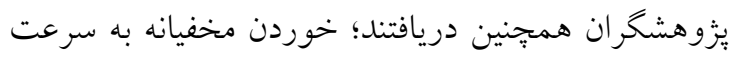




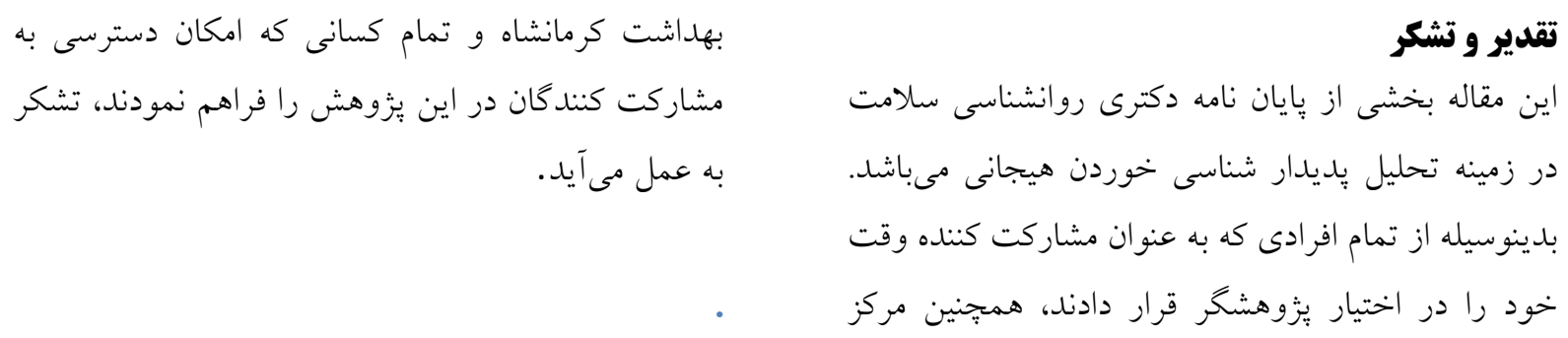

\section{References}

1. Van Strien T. Causes of emotional eating and matched treatment of obesity. Current diabetes reports. 2018;18(6):1-8.

2. Elfhag K, Morey LC. Personality traits and eating behavior in the obese: poor self-control in emotional and external eating but personality assets in restrained eating. Eating behaviors. 2008;9(3):285-93.

3. Nguyen-Michel ST, Unger JB, Spruijt-Metz D. Dietary correlates of emotional eating in adolescence. Appetite. 2007;49(2):494-9.

4. Cartwright M, Wardle J, Steggles N, Simon AE, Croker H, Jarvis MJ. Stress and dietary practices in adolescents. Health psychology. 2003;22(4):362.

5. Wardle J, Steptoe A, Oliver G, Lipsey Z. Stress, dietary restraint and food intake. J Psychosomatic Res. 2000;48(2):195-202.

6. Teo PS, van Dam RM, Forde CG. Combined Impact of a Faster Self-Reported Eating Rate and Higher Dietary Energy Intake Rate on Energy Intake and Adiposity. Nutrients. 2020;12(11):3264.

7. Konttinen H, Haukkala A, Sarlio-Lähteenkorva S, Silventoinen K, Jousilahti P. Eating styles, selfcontrol and obesity indicators. The moderating role of obesity status and dieting history on restrained eating. Appetite. 2009;53(1):131-4.

8. Radzevičienè L, Ostrauskas R. Fast eating and the risk of type 2 diabetes mellitus: a case-control study. Clinical nutrition. 2013;32(2):232-5.

9. Zhu B, Haruyama Y, Muto T, Yamazaki T. Association between eating speed and metabolic syndrome in a three-year population-based cohort study. J Epidemiol. 2015;25(4): 332-6.

10. Teo PS, van Dam RM, Whitton C, Tan LW, Forde CG. Association between self-reported eating rate, energy intake, and cardiovascular risk factors in a multi-ethnic Asian population. Nutrients. 2020;12(4):1080.

11. White CA. Cognitive behaviour therapy for chronic medical problems: A guide to assessment and treatment in practice. John Wiley \& Sons Ltd; 2001.

12. Fox S, Conneely S, Egan J. Emotional expression and eating in overweight and obesity. Health Psychol Behav Medic. 2017;5(1):337-57.

13. Alibakhshi Z, Alipour A, Farzad V, Aliakbari M. Mediating role of emotional eating, self-esteem and self-control in modeling of obesity in adolescent girls. Journal of Mazandaran University of Medical Sciences. 2016;25(134):193-208. [Persian]

14. Nguyen-Rodriguez ST, Chou CP, Unger JB, Spruijt-Metz D. BMI as a moderator of perceived stress and emotional eating in adolescents. Eating behaviors. 2008;9(2):238-46.

15. Wu J, Willner CJ, Hill C, Fearon P, Mayes LC, Crowley MJ. Emotional eating and instructed foodcue processing in adolescents: An ERP study. Biological psychology. 2018;132:27-36.

16. Ho AY. Risk Factors of Emotional Eating Among Undergraduates. Case Western Reserve University; 2014. [http://rave.ohiolink.edu/etdc/view?acc_num=case1402059723]

17. Luomala HT, Sirieix L, Tahir R. Exploring emotional-eating patterns in different cultures: Toward a conceptual framework model. J Int Consum Market. 2009;21(3):231-45.

18. Hossein Abbasi N, Mehrdad N, Nikbakht Nasrabadi A. Hidden trauma in overweight women. Iranian Journal of Nursing Research. 2017;11(6):14-22. [Persian]

19. Polit DF, Beck CT. Nursing research: Principles and methods. $9^{\text {th }}$ ed. Philadelphia, USA: Lippincott Williams \& Wilkins; 2012.

20. Close J. Women's Experiences of Comfort Eating: An Interpretative Phenomenological Analysis (Doctoral dissertation, University of Leicester), England: University of Leicester; 2013. 
21. Katsounari I, Zeeni N. Preoccupation with weight and eating patterns of Lebanese and Cypriot female students. Psychology. 2012;3(06):507-12.

22. Fay SH, Finlayson G. Negative affect-induced food intake in non-dieting women is reward driven and associated with restrained-disinhibited eating subtype. Appetite. 2011;56(3):682-8.

23. Salehi-Fadardi J, Moghaddaszadeh-Bazzaz M, Amin-Yazdi A, Nemati M. The Role of Attentional Bias and Eating Styles in Dieters. Journal of Clinical Psychology. 2013;5(17): 57-67. [Persian]

24. Ogden J, Wardle J. Cognitive and emotional responses to food. Int J Eating Disord. 1991;10(3):297-311.

25. Ford T, Lee H, Jeon M. The emotional eating and negative food relationship experiences of obese and overweight adults. Social work in health care. 2017;56(6):488-504.

26. Heatherton TF, Baumeister RF. Binge eating as escape from self-awareness. Psychological bulletin. 1991;110(1):86-108.

27. Gouveia MJ, Canavarro MC, Moreira H. Associations between mindfulness, self-compassion, difficulties in emotion regulation, and emotional eating among adolescents with overweight/obesity. J Child Fam Stud. 2019;28(1):273-85.

28. Liu H, Yang Q, Luo J, Ouyang Y, Sun M, Xi Y, Yong C, Xiang C, Lin Q. Association between emotional eating, depressive symptoms and laryngopharyngeal reflux symptoms in college students: A cross-sectional study in Hunan. Nutrients. 2020;12(6):1595.

29. Ogden J, Avenell S, Ellis G. Negotiating control: patients' experiences of unsuccessful weight-loss surgery. Psychology \& Health. 2011;26(7):949-64.

30. Stroebe W, Mensink W, Aarts H, Schut H, Kruglanski AW. Why dieters fail: Testing the goal conflict model of eating. J Experim Social Psychol. 2008;44(1):26-36.

31. Van Ostrand G. Why some women eat too much: A qualitative study of food-dependent women (Doctoral dissertation, Walden University).2015.

32. Davis C, Curtis C, Levitan RD, Carter JC, Kaplan AS, Kennedy JL. Evidence that 'food addiction'is a valid phenotype of obesity. Appetite. 2011;57(3):711-7.

33. Tatsi E, Kamal A, Turvill A, Regina H. Emotion dysregulation and loneliness as predictors of food addiction. Journal of Health and Social Sciences. 2019; 4(1):43-58.

34. Pivarunas B, Conner BT. Impulsivity and emotion dysregulation as predictors of food addiction. Eating behaviors. 2015;19:9-14.

35. Gearhardt AN, White MA, Masheb RM, Morgan PT, Crosby RD, Grilo CM. An examination of the food addiction construct in obese patients with binge eating disorder. Int $J$ Eating Disord. 2012;45(5):657-63.

36. Evers C, Marijn Stok F, de Ridder DT. Feeding your feelings: Emotion regulation strategies and emotional eating. Personal Social Psychol Bulletin. 2010;36(6):792-804.

37. Spoor ST, Bekker MH, Van Strien T, van Heck GL. Relations between negative affect, coping, and emotional eating. Appetite. 2007;48(3):368-76.

38. Bassak Nejad S, Aarefi N, Arshadi N. Testing a model of Emotional Eating, Emotional Dysregulation, Self-Esteem, and Impulsivity in Food Addiction among students. Quarterly Journal of Health Psychology. 2018;7(26):132-45.

39. Jáuregui-Lobera I, Montes-Martínez M. Emotional eating and obesity. InPsychosomatic Medicine 2020 Mar 13. IntechOpen.

40. Hebebrand J, Albayrak Ö, Adan R, Antel J, Dieguez C, De Jong J, Leng G, Menzies J, Mercer JG, Murphy M, Van Der Plasse G. "Eating addiction", rather than "food addiction", better captures addictive-like eating behavior. Neuroscience \& Biobehavioral Reviews. 2014;47:295-306.

41. van Strien T. Ice-cream consumption, tendency toward overeating, and personality. Int $J$ Eating Disord. 2000;28(4):460-4.

42. Macht M, Meininger J, Roth J. The pleasures of eating: A qualitative analysis. J Happin Stud. 2005;6(2):137-60.

43. Komatsu S. Rice and sushi cravings: a preliminary study of food craving among Japanese females. Appetite. 2008;50(2-3):353-8.

44. Hernandez-Hons A, Woolley SR. Women's experiences with emotional eating and related attachment and sociocultural processes. J Marital Family Therapy. 2012;38(4):589-603.

45. Lydecker JA, Grilo CM. I didn't want them to see: Secretive eating among adults with binge-eating disorder. Int J Eating Disord. 2019;52(2):153-8. 